\title{
Exhaust emission factors of greenhouse gases (GHGs) from European road vehicles
}

\author{
Michaël Clairotte* (iD, Ricardo Suarez-Bertoa, Alessandro A. Zardini, Barouch Giechaskiel, Jelica Pavlovic,
} Victor Valverde, Biagio Ciuffo and Covadonga Astorga*

\begin{abstract}
Background: Road transport is an important contributor to the European Union's total greenhouse gas emissions. This study aims at summarizing methane $\left(\mathrm{CH}_{4}\right)$ and nitrous oxide $\left(\mathrm{N}_{2} \mathrm{O}\right)$ exhaust emissions from L-category, light-duty and heavy-duty vehicles in the European Union. The assessment is based on measurements carried out in the Vehicle Emission Laboratory of the Joint Research Centre between 2009 and 2019. The exhaust chemical composition from a fleet of 38 L-category vehicles Euro 1 to Euro 4 (2- and 3-wheelers, small quadricycles such as quads and minicars), 63 light-duty vehicles from Euro 5b to Euro 6d-TEMP (passenger cars, including hybrid vehicles), and 27 light commercial and heavy-duty vehicles from pre-Euro I to Euro VI (including lorries, buses and garbage trucks) was analyzed by Fourier-transform infrared spectroscopy.

Results: $\mathrm{CH}_{4}$ emission factors monitored were from 1 to $234 \mathrm{mg} / \mathrm{km}$ for L-category vehicles (mean: $39 \mathrm{mg} / \mathrm{km}$ ), from 0.1 to $40 \mathrm{mg} / \mathrm{km}$ for light-duty vehicles (mean: $7 \mathrm{mg} / \mathrm{km}$ ), and from non-detectable to $320 \mathrm{mg} / \mathrm{km}$ for heavy-duty vehicles (mean: $19 \mathrm{mg} / \mathrm{km}$ ). $\mathrm{N}_{2} \mathrm{O}$ emission factors monitored were from non-detectable to $5 \mathrm{mg} / \mathrm{km}$ for L-category vehicles (mean: $1 \mathrm{mg} / \mathrm{km}$ ), from non-detectable to $40 \mathrm{mg} / \mathrm{km}$ for light-duty vehicles (mean: $7 \mathrm{mg} / \mathrm{km}$ ), and from non-detectable to $118 \mathrm{mg} / \mathrm{km}$ for heavy-duty vehicles (mean: $19 \mathrm{mg} / \mathrm{km}$ ). According to the 100-year Global Warming Potential of these greenhouse gases, these emissions corresponded to a range from negligible up to $9 \mathrm{~g} / \mathrm{km}$ of $\mathrm{CO}_{2}$-equivalent for $\mathrm{CH}_{4}$ and from negligible up to $32 \mathrm{~g} / \mathrm{km}$ of $\mathrm{CO}_{2}$-equivalent for $\mathrm{N}_{2} \mathrm{O}$.

Conclusions: The higher contributors of $\mathrm{CH}_{4}$ were the two-stroke mopeds included in the L-category vehicles, while the higher emissions of $\mathrm{N}_{2} \mathrm{O}$ were found in the modern (Euro 5-6 or Euro V-VI) diesel light- and heavy-duty vehicles. Among them, vehicles complying with Euro 6 and Euro VI standard were associated to higher $\mathrm{N}_{2} \mathrm{O}$ emissions compared to those associated to Euro 5 and pre-Euro IV standards, which could be attributed to the introduction of the after-treatment systems designed to fulfill more stringent NOx standards. These updated emission factors and unique on its kind database represent a source of information for legislators and modelers to better assess the greenhouse gas emission reduction in the EU transport sector.
\end{abstract}

Keywords: Greenhouse gases, $\mathrm{CO}_{2}$, Methane, Nitrous oxide, On-road transport, Emission factors

\section{Highlights}

- Greenhouse gas emission factors from 128 L-category, light- and heavy-duty vehicles

- $\mathrm{CH}_{4}$ emission factors ranged from 0 to $320 \mathrm{mg} / \mathrm{km}$
- $\mathrm{N}_{2} \mathrm{O}$ emissions ranged from 0 to $118 \mathrm{mg} / \mathrm{km}$

- High $\mathrm{CH}_{4}$ emissions from two-stroke mopeds included in the L-category vehicles

- High $\mathrm{N}_{2} \mathrm{O}$ emissions from modern Euro6/EuroVI diesel light- and heavy-duty vehicles.

\footnotetext{
*Correspondence: michael.clairotte@ec.europa.eu; covadonga. astorga-Ilorens@ec.europa.eu

European Commission, Joint Research Centre, 21027 Ispra, Italy
}

\section{Springer Open}

(c) The Author(s) 2020. This article is licensed under a Creative Commons Attribution 4.0 International License, which permits use, sharing, adaptation, distribution and reproduction in any medium or format, as long as you give appropriate credit to the original author(s) and the source, provide a link to the Creative Commons licence, and indicate if changes were made. The images or other third party material in this article are included in the article's Creative Commons licence, unless indicated otherwise in a credit line to the material. If material is not included in the article's Creative Commons licence and your intended use is not permitted by statutory regulation or exceeds the permitted use, you will need to obtain permission directly from the copyright holder. To view a copy of this licence, visit http://creativeco mmons.org/licenses/by/4.0/. 


\section{Background}

Methane $\left(\mathrm{CH}_{4}\right)$ and nitrous oxide $\left(\mathrm{N}_{2} \mathrm{O}\right)$ are long-lived greenhouse gases (GHG), with atmospheric lifetimes of 12 and 121 years, respectively. Considering their radiative forcing, $\mathrm{CH}_{4}$ and $\mathrm{N}_{2} \mathrm{O}$ have a 100 -year time horizon global warming potentials (GWP) of 28 and $265 \mathrm{CO}_{2}$ equivalent $\left(\mathrm{CO}_{2}\right.$-eq), respectively [41]. Over the last 250 years (i.e. beginning of industrial revolution), $\mathrm{CO}_{2}$, $\mathrm{CH}_{4}$ and $\mathrm{N}_{2} \mathrm{O}$ global concentration in the atmosphere increased by $42 \%, 154 \%$ and $21 \%$, respectively [5]. With an average growth of $9.4 \mathrm{ppb} /$ year between 2014 and 2017, the increase of atmospheric $\mathrm{CH}_{4}$ was speeding up during the last years [49]. Natural sources are the main contributors of global $\mathrm{N}_{2} \mathrm{O}$ emission, with a rough estimate of $11 \mathrm{Tg} \mathrm{N}{ }_{2} \mathrm{O}-\mathrm{N} /$ year [41]. However, with an emission rate of about $5.3 \mathrm{Tg} \mathrm{N} \mathrm{N}_{2} \mathrm{O}-\mathrm{N} /$ year, up to a third of the global $\mathrm{N}_{2} \mathrm{O}$ emissions is most likely to be anthropogenic [13]. Industry sector and fossil fuel combustion are responsible of $15 \%$ of the $\mathrm{N}_{2} \mathrm{O}$ anthropogenic emission [63]. With a share ranging from 50 to $60 \%$, human activities are the main sources of global $\mathrm{CH}_{4}$ emissions $[7,50]$. In the European Union (EU), GHG emissions decreased in the majority of anthropogenic sectors between 1990 and 2014, however, road transport is still associated to the largest increase of $\mathrm{CO}_{2}$ in this period with a growth of $124 \mathrm{MT}$, and 7 MT between 2013 and 2014 [28]. Moreover, $73 \%$ of the GHG emissions from transport sector in EU-28 came from the road sector in 2015, which represented ca. $19 \%$ of the total GHG emissions in the EU-28 [27].

Methane is a GHG and a precursor of tropospheric ozone. Together with other hydrocarbons, methane is released during incomplete combustion of fuel. $\mathrm{CH}_{4}$ is particularly resistant to catalytic oxidation, and mostly associated to the cold start of the vehicles [45]. In a study carried out on light-duty vehicles equipped with a catalytic converter, it was found that catalyst light-off duration (e.g. time needed by the catalyst system to reach its required conversion efficiency) for methane was systematically longer than for the overall hydrocarbons [9]. Therefore, methane emission level from transport can be amplified when cold start events are repeated (e.g. over short trips), or lasting for an extended period (e.g. vehicle start up at low ambient temperature). $\mathrm{CH}_{4}$ emissions are also associated to natural gas engines, for which the emission factors could exceed by a factor of 10 the emissions factor from conventional gasoline passenger cars $[45,48]$.

Nitrous oxide from transportation is formed during both, combustion and catalytic processes. Through fuel combustion, $\mathrm{N}_{2} \mathrm{O}$ results from the gas-phase reactions of nitric oxide $(\mathrm{NO})$ with either hydrogen cyanide $(\mathrm{HCN})$ or ammonia $\left(\mathrm{NH}_{3}\right)$. Such process is, however, limited by the concentration of the reactants in the exhaust, as well as the thermal stability of the $\mathrm{N}_{2} \mathrm{O}$ generated in combustion conditions [38]. Modern catalytic converters for NOx, $\mathrm{CO}$ and hydrocarbons removals have been associated with $\mathrm{N}_{2} \mathrm{O}$ emissions $([37,45,67])$. The widespread aftertreatment system used nowadays for vehicle fueled with gasoline is the three-way catalyst (TWC). Such catalytic system removes pollutants in exhaust gas through oxidation of the $\mathrm{CO}$ and hydrocarbons and also by reduction of NOx. However, the latter chemistry involved undesirable reactions between $\mathrm{NO}$ and nitrogen at the catalyst surface that results in $\mathrm{N}_{2} \mathrm{O}$ formation [67]. In case of diesel fueled cars and trucks, a series of after-treatment systems were developed to tackle unwanted pollutants created from lean fuel combustion. The most commonly systems used are diesel oxidation catalyst (DOC), lean-NOx trap/ NOx Storage Catalyst (LNT/NSC), and selective catalytic reduction (SCR). $\mathrm{N}_{2} \mathrm{O}$ can be formed over a large range of chemical reactions, at different temperatures through chemistry involving ammonia $\left(\mathrm{NH}_{3}\right)$ as precursor. Extensive description of $\mathrm{N}_{2} \mathrm{O}$ formation mechanism can be found in Guan et al. [37] and references therein.

Considering the importance of the transport sector in the global GHG emissions budget and the broad use of after-treatment systems (implemented to comply with the increasingly stringent emission standards), $\mathrm{CH}_{4}$ and $\mathrm{N}_{2} \mathrm{O}$ from mobile sources have been progressively regulated. In the United States, the Environmental Protection Agency (US-EPA) together with the National Highway Traffic Safety Administration (NHTSA) have set a regulation to control the GHG tailpipe emission from lightduty vehicles (LDV), with limits of 30 and $10 \mathrm{mg} / \mathrm{mile}$ for $\mathrm{CH}_{4}$ and $\mathrm{N}_{2} \mathrm{O}$, respectively. The objective was to cap these emissions with standards aiming at avoiding future increase related to the implementation of new engines and technology. In addition, US-EPA also implemented a standard for heavy-duty engines, pick-up trucks and vans with a limit for $\mathrm{N}_{2} \mathrm{O}$ of $0.10 \mathrm{~g} / \mathrm{bhp}-\mathrm{h}$ [29]. In China, through the China's stage 6 emission standard, a limit ranging from 20 to $30 \mathrm{mg} / \mathrm{km}$ was defined for tailpipe $\mathrm{N}_{2} \mathrm{O}$ emission (to be applied from July 2020). In the EU, methane is directly regulated for the heavy-duty gas engines since the Euro III standard (in 2000) and the current limit is set to $0.5 \mathrm{~g} / \mathrm{kWh}$ [22]. No specific $\mathrm{CH}_{4}$ standard is defined for light-duty vehicles. However, methane is indirectly regulated through two limits set for total hydrocarbons (THC, $100 \mathrm{mg} / \mathrm{km}$ ) and non-methane hydrocarbons (NMHC, $68 \mathrm{mg} / \mathrm{km}$ ) starting from Euro 5 standard for gasoline LDV [24]. The same THC and $\mathrm{NMHC}$ limit values as those for light-duty vehicles are prescribed for L-category vehicles starting from the Euro 5 environmental step which be enforced from 2020 (Regulation EU 168/2013). A cost-benefit analysis to confirm 
the measures of Regulation EU 168/2013 was performed in an environmental effect study carried out for the Euro 5 L-category step [19]. Regarding the $\mathrm{N}_{2} \mathrm{O}$, although the EU undertakes initiatives to promote clean and energy efficient vehicles (e.g. included in Horizon 2020 programme-[16, 23]), no standard is defined in the EU so far.

In the EU, Regulation (EU) 2019/631 is in force to encourage car manufacturers to contribute to the $\mathrm{CO}_{2}$ reduction [14]. This regulatory text set mandatory fleetaverage $\mathrm{CO}_{2}$ emissions targets for passenger cars and light commercial vehicles, with a reduction phased in gradually over a period of time. While the overall target of the EU fleet-wide average emission for new cars is set to $95 \mathrm{~g} / \mathrm{km} \mathrm{CO}_{2}$ from 2021, this target will be reduced further the subsequent years. In addition, this Regulation defined the Eco-innovation scheme which was set to encompass innovative technologies that contribute to $\mathrm{CO}_{2}$ reduction but that cannot be assessed over the standard laboratory tests [20]. Through use of such technologies, a manufacturer can earn $\mathrm{CO}_{2}$ credits of up to $7 \mathrm{~g} / \mathrm{km} \mathrm{CO}_{2}$, with a minimum reduction achieved by the innovative technology of at least 1 or $0.5 \mathrm{~g} / \mathrm{km} \mathrm{CO}_{2}$ depending on the reference standard test procedure. This $\mathrm{CO}_{2}$ credits are counted when calculating the EU overall target of the manufacturer. Regarding the heavy-duty vehicles, Regulation (EU) 20019/1242 defines $\mathrm{CO}_{2}$ standards for average emissions, with a stepwise reduction of the targets from 2025 and 2030 [15].

GHGs emission factors from on-road transport are available in the literature, like from two-wheelers $[8,9$, 69, 70], from passenger cars $[3,9,32-34,39,40,42,44$, $53,66]$, and trucks and buses $[2,4,31,35,36,45,46$, $52,59,60]$. However, most of these studies are based on either few vehicles, or vehicles complying with outdated emission standards. The novelty of this study is the presentation of current GHGs emissions factors measured from large fleet of vehicles belonging to the different vehicle categories. Vehicles complying with the latest emissions standards were investigated. The most important GHGs emissions, namely $\mathrm{CH}_{4}, \mathrm{~N}_{2} \mathrm{O}$ and $\mathrm{CO}_{2}$, have been estimated through experimental measurements of tailpipe emissions from a fleet composed of 128 in-service L-category, light-duty and heavy-duty vehicles tested between 2009 and 2019.

\section{Materials and methods}

\section{Chassis dynamometer experiments}

To assess GHG tailpipe emissions from on-road transportation, chassis dynamometer measurement campaigns were conducted at the European Commission Joint Research Centre (JRC) Ispra, Italy, in three Vehicle Emission Laboratories (VELA). The data were collected during 11 years from 2009 to 2019 . The facility dedicated to L-category vehicles emissions measurement was composed of a chassis dynamometer (one roller with $48^{\prime \prime}$ diameter, inertia range 150-3500 kg, Zoellner GmbH, Germany), a Constant Volume Sampler (CVS, flow rate range $1.5-11.25 \mathrm{~m}^{3} / \mathrm{min}$ ) with a critical flow venturi, and gas analyzer benches (CEB II and AMA i60 for the raw exhaust and for the dilution tunnel and bags, AVL, Graz, Austria). The facility dedicated to light-duty vehicles emissions measurement was composed of a chassis dynamometer (two rollers with $48^{\prime \prime}$ diameter, inertia range 454-4540 kg, MAHA Haldenwang, Germany), a Constant Volume Sampler (CVS, flow rate range 3-30 $\mathrm{m}^{3}$ min) with a critical flow venturi, and gas analyzer benches (MEXA-7100 for the raw exhaust and MEXA-7400 for the dilution tunnel and bags, HORIBA, Japan). The facility dedicated to heavy-duty vehicles emissions measurement was composed of a chassis dynamometer (two rollers with $72^{\prime \prime}$ diameter, inertia range $800-30,000 \mathrm{~kg}$, Zoellner GmbH, Germany), a Constant Volume Sampler (CVS, flow rate range $10-150 \mathrm{~m}^{3} / \mathrm{min}$ ) with four critical flow venturi, and gas analyzer benches (AMA i60 for both the raw exhaust and the dilution tunnel and bags, AVL, Graz, Austria). The exhaust flow rate was calculated using the difference between the total flow and the diluted flow rates and very often cross-checked with the $\mathrm{CO}_{2}$ tracer method. A maximum $10 \%$ uncertainty was estimated [30]. A description of the experimental system is illustrated in Additional file 1: Figure S1.

The vehicles were tested at $22-25{ }^{\circ} \mathrm{C}$, over their typeapproval test cycles applicable in $\mathrm{EU}$, and over their foreseen test cycles defined in the upcoming legislation that are considered more realistic. Thus, these GHG emission factors can better represent tailpipe emission reported so far for the in-service EU fleet. The L-cat were driven over the R47, R40 (according to Directive 2002/51/EC [25]) and the Worldwide harmonized Motorcycle Testing Cycle (WMTC stage 3-according to Regulation 134/2014 [18]). LDV were tested over the New European Driving Cycle (NEDC - according to Regulation No. 83 [62]) and the Worldwide harmonized Light vehicles Test Cycle (WLTC Class 3-according to Regulation 2017/1151 [17]). The HDV were tested over the chassis dynamometer version of the European Transient Cycle (ETC). Unlike the engine dynamometer version (Directive 1999/96/EC [26]), the ETC chassis version is not used for type approval testing. One Euro VI HDV was tested with the Worldwide Harmonized Vehicle Cycle (WHVC), which was developed based on the same set of data used for the development of the engine type approval Worldwide Harmonized Test Cycle (WHTC), the type approval cycle of Euro VI engines. Unlike the WHTC, the WHVC is not used for regulatory testing. In addition, tailpipe GHG emissions from several heavy-duty vehicles were 
also monitored over on-road tests, and over laboratory test reproducing the on-road conditions (in-service conformity-ISC-cycle including vehicle speed and road slope). Driving cycles used in this study are illustrated in Additional file 1: Figure S2.

\section{Vehicle fleet}

Table 1 summarizes the main features of the 128 vehicles studied. The fleet was composed of $38 \mathrm{~L}$-category vehicles (L-cat), including mopeds (category L1e), motorcycles (L3e), tricycles (L5e) and quadricycles (L6e-L7e), with engine capacity ranging from 30 to $1170 \mathrm{~cm}^{3}$, engine power from 0.5 to $92 \mathrm{~kW}$, emission standard from Euro 1 to Euro 4. A substantial part of the L-cat was selected in the scope of the environmental effect study on the Euro 5 step of L-cat [68]. The fleet of light-duty vehicles (LDV) was composed of 63 vehicles equipped with positive and compression ignitions engines, as well as hybrids (gasoline), dual-fuel (Gasoline/Liquefied petroleum gas (LPG)) and flexi-fuel (running with up to $85 \%$ ethanol) vehicles. The LDV engine capacity ranged from 875 to $2996 \mathrm{~cm}^{3}$, engine power from 51 to $330 \mathrm{~kW}$, and emission standards from Euro 5b to Euro 6d-TEMP. A large part of the LDV were selected in the scope of the EC-JRC contribution to the preparation of the European Union market surveillance of vehicle emissions, and more details on the selection procedure can be found in the corresponding reports $([10,64])$. The fleet of light commercial and heavy-duty vehicles (HDV hereinafter) was composed 4 light commercial and 23 heavy-duty vehicles, including semitrailers, garbage trucks and buses. These vehicles were mostly equipped with compression ignitions engines. In addition, tailpipe emissions from one light commercial vehicle and one truck equipped with dual-fuel engines using Compressed Natural Gas (CNG; CNG/Diesel), and one truck with dual-fuel engine using LPG (LPG/Diesel) were measured. The light commercial and heavy-duty vehicle engine capacity ranged from 1560 to $12,920 \mathrm{~cm}^{3}$, engine power from 73 to $368 \mathrm{~kW}$, and emission standard from Pre-Euro I to Euro VI (from Euro 3 to Euro $6 \mathrm{~b}$ for the 4 light commercial vehicles). Fuel used was market CNG (> 85\% methane), LPG, diesel (B5 or B7) or gasoline fuel (E5 or E10), unless otherwise specified (E85).

A minimum of two tests were carried out for each combination of vehicle and cycles investigated. When two different driving cycles were carried out for one vehicle, the emission factors reported is the average of the mean emission factor obtained over each cycle. Values reported for dual-fuel vehicles were those recorded when CNG and LPG fuels were used. More technical details on the fleet as well as on the cycles used can be found in Additional file 1: Tables S1-S3.

\section{Measuring equipment}

$\mathrm{N}_{2} \mathrm{O}$ and $\mathrm{CH}_{4}$ measurement were carried out using Fourier-transform Infrared spectroscopy (FTIR) technique. For this scope, two FTIR instruments were connected to the raw exhaust at the vehicle tailpipe, using a heated polytetrafluoroethylene sampling line $\left(191{ }^{\circ} \mathrm{C}\right)$. The first FTIR spectrometer (Nicolet Antaris IGS Analyzer-Thermo Electron Scientific Instruments LLC, Madison, WI, USA) was equipped with a multipath gas cell with $2 \mathrm{~m}$ of optical path, a downstream sampling pump (6.5 $1 \mathrm{~min}^{-1}$ flowrate) and had the acquisition frequency of $1 \mathrm{~Hz}$ with a working pressure of $860 \mathrm{hPa}$. The second FTIR spectrometer (Multigas analyzer 2030-MKS,

Table 1 Summary of the vehicles tested

\begin{tabular}{|c|c|c|c|c|c|c|}
\hline Category & Fuel & $\begin{array}{l}\text { Number of vehicles } \\
\text { tested }\end{array}$ & $\begin{array}{l}\text { Min engine } \\
\text { capacity }\left(\mathrm{cm}^{3}\right)\end{array}$ & $\begin{array}{l}\text { Max engine } \\
\text { capacity }\left(\mathrm{cm}^{3}\right)\end{array}$ & $\begin{array}{l}\text { Min engine power } \\
(\mathrm{kW})\end{array}$ & $\begin{array}{l}\text { Max engine } \\
\text { power (kW) }\end{array}$ \\
\hline \multirow[t]{4}{*}{ L-cat } & Gasoline + oil & 10 & 30 & 50 & 0.5 & 5 \\
\hline & Gasoline & 24 & 50 & 1170 & 1.2 & 92 \\
\hline & Diesel & 3 & 400 & 480 & 4 & 4.9 \\
\hline & Gasoline hybrid & 1 & 278 & - & 18.2 & - \\
\hline \multirow[t]{5}{*}{ LDV } & Gasoline & 26 & 875 & 1997 & 51 & 155 \\
\hline & Diesel & 28 & 1248 & 2993 & 55 & 195 \\
\hline & Gasoline hybrid & 5 & 1395 & 2996 & 73 & 330 \\
\hline & Dual-LPG & 1 & 1368 & - & 88 & - \\
\hline & Flex-fuel (E85) & 3 & 1596 & 1600 & 112 & 132 \\
\hline \multirow[t]{3}{*}{ LCV and HDV } & Diesel & 24 & 1560 & 12,920 & 73 & 368 \\
\hline & Dual-LPG & 1 & 12,920 & - & 340 & - \\
\hline & Dual-CNG & 2 & 2999 & 3920 & 100 & 110 \\
\hline
\end{tabular}

L-cat covers mopeds, motorcycles and quads. Light-duty vehicles (LDV) are passenger cars. Light commercial vehicles (LCV-4 in total) are included in the heavy-duty vehicles (HDV) category 
Wilmington, MA, USA) was equipped with a multipath gas cell with $5.11 \mathrm{~m}$ of optical path, an upstream heated pump (10 $1 \mathrm{~min}^{-1}$ flowrate) and had an acquisition frequency of $1 \mathrm{~Hz}$ with a working pressure of $1013 \mathrm{hPa}$. The two FTIR spectrometers were made up with a Michelson interferometer (spectral resolution: $0.5 \mathrm{~cm}^{-1}$, spectral range: $600-3500 \mathrm{~cm}^{-1}$ ) and a liquid nitrogen cooled mercury cadmium telluride detector. Results obtained with the two instruments were found in good agreement with the VELA results obtained following regulated measurement procedures (less than $10 \%$ differences for the commonly measured pollutants, like $\mathrm{CO}, \mathrm{CO}_{2}$, $\mathrm{NOx}$ and $\mathrm{CH}_{4}$ ). The FTIR spectrometers detection limits were 0.6 and 0.4 ppmv for $\mathrm{CH}_{4}$ and $\mathrm{N}_{2} \mathrm{O}$, respectively. More details on FTIR technique as well as on the $\mathrm{CH}_{4}$ and $\mathrm{N}_{2} \mathrm{O}$ emission factor calculation can be found in the literature $[8,57])$. The $\mathrm{CO}_{2}$ measurement was conducted on bags sampling connected at the dilution tunnel, using nondispersive infrared analyzer, following the requirements defined in EU Regulations [17, 18, 25, 62]. It has to be noted that $\mathrm{CO}_{2}$ emission factors depend substantially on the road load simulated by the chassis dynamometer. In this study, a mix of tabulated road load values (defined in the Regulation [62]), and calculated road load values (using an approach derived from a JRC database of vehicles for which road loads were known and provided by Original Equipment Manufacturer (OEM) - more details can be found in [61]) were used. Finally, for LDV to be consistent with NEDC data, no correction was applied on the $\mathrm{CO}_{2}$ emission factors obtained from WLTC (no correction based on the states of charge of the battery, or on the ambient temperature).

In addition to the descriptive statistics, statistical inferences were conducted to investigate the effect of engine technology and vehicle emission standard on GHGs emissions. For the hypothesis testing, multiple pairwise comparisons of each group were achieved. For the LDV, two different driving cycles were applied (NEDC and WLTC), the statistical inference was conducted only on the emissions obtained over the WLTC. This approach was adopted to avoid the driving cycle type to be a confounder in the inference analysis, as NEDC was only applied on LDV compliant with the Euro5b and Euro6b standard (Additional file 1: Table S2). Finally, as the requirements for one-way ANOVA test were not verifiable due to the low number of vehicles per group (nonnormal distribution in each factor level), an alternative non-parametric method was applied (Kruskal-Wallis test- $5 \%$ significance level). The statistical analysis was carried out with $\mathrm{R}$ software (version 3.3.2).

In "Results" section, the range of $\mathrm{CH}_{4}, \mathrm{~N}_{2} \mathrm{O}$ and $\mathrm{CO}_{2}$ tailpipe emissions are presented for the whole fleet of vehicle studied. Discussions on these emissions, and on the effect of the fuel and engine technology are included in "Discussion" section.

Concluding, the chassis dynamometer measurements ensured well-controlled conditions for the instruments, and on the other hand, using realistic cycles (WMTC, WLTC) we believe that the emission factors are representative of the real on-road operation of the vehicles. This will be further discussed in "Comparison of data with the literature values" section.

\section{Results \\ $\mathrm{CH}_{4}$ emission factors}

Methane emissions from the fleet of vehicles studied are presented in Fig. 1. The average emissions of $\mathrm{CH}_{4}$ from the L-cat ranged from 3 to $109 \mathrm{mg} / \mathrm{km}$ (with one exception $232 \mathrm{mg} / \mathrm{km}$ ). L-cat vehicles equipped with 2-stroke engines, mainly mopeds and one motor assisted bicycle (fueled with 50:1 vol/vol gasoline/lube oil mix-Veh. 1-10) displayed average $\mathrm{CH}_{4}$ emissions ranging from 10 to $109 \mathrm{mg} / \mathrm{km}$. These vehicles were complying with the Euro 1 and Euro 2 standards. Vehicles fueled with gasoline only (Veh. 11-30 and 34-38) displayed average $\mathrm{CH}_{4}$ emissions ranging from 7 to $73 \mathrm{mg} / \mathrm{km}$ with one specific vehicle (Veh. 28) displaying substantially high levels of $\mathrm{CH}_{4}$ emissions, $232 \mathrm{mg} / \mathrm{km}$. This specific vehicle was a tampered high-performance motorcycle. As this study aimed at investigating the realistic GHG emissions from in-use vehicles, the value provided a good indication of what can be expected from the illegal practice of tampering $\mathrm{L}$-cat vehicles to obtain more delivered power (results from this outlier vehicle were not taken into account in the further statistical analysis). One hybrid-gasoline L-cat vehicle was included in the fleet (Veh. 29), and tested in charge sustaining mode (i.e. using mostly the combustion engine). Not surprisingly, $\mathrm{CH}_{4}$ emission of this vehicle was in the range of the emissions obtained with the L-cat fueled with gasoline only. Regarding the vehicles fueled with diesel (three commercial tricycles and light quadricycles-Veh. 31-33), the range of methane emission factors was relatively lower compared to the other L-cats, with a maximum emission factor of $5 \mathrm{mg} / \mathrm{km}$.

Average methane emissions from the LDV ranged from $<1$ to $40 \mathrm{mg} / \mathrm{km}$, with gasoline and hybrid vehicles (tested in charge sustaining mode) emitting between $<1$ and $10 \mathrm{mg} / \mathrm{km}$, and diesel vehicles emitting between 2 and $40 \mathrm{mg} / \mathrm{km}$. The three vehicles fueled with a mixture of gasoline with $85 \% \mathrm{v} / \mathrm{v}$ ethanol (E85) (Veh. 99-101) displayed $\mathrm{CH}_{4}$ emissions from 9 to $20 \mathrm{mg} / \mathrm{km}$, while the dual-fuel vehicle (Veh. 98) had an average $\mathrm{CH}_{4}$ emission of $2 \mathrm{mg} / \mathrm{km}$.

Methane emissions from $27 \mathrm{HDV}$, including four light commercial vehicles were up to $320 \mathrm{mg} / \mathrm{km}$. Apart from three dual-fuel vehicles (two dual CNG-Veh. 105 and 


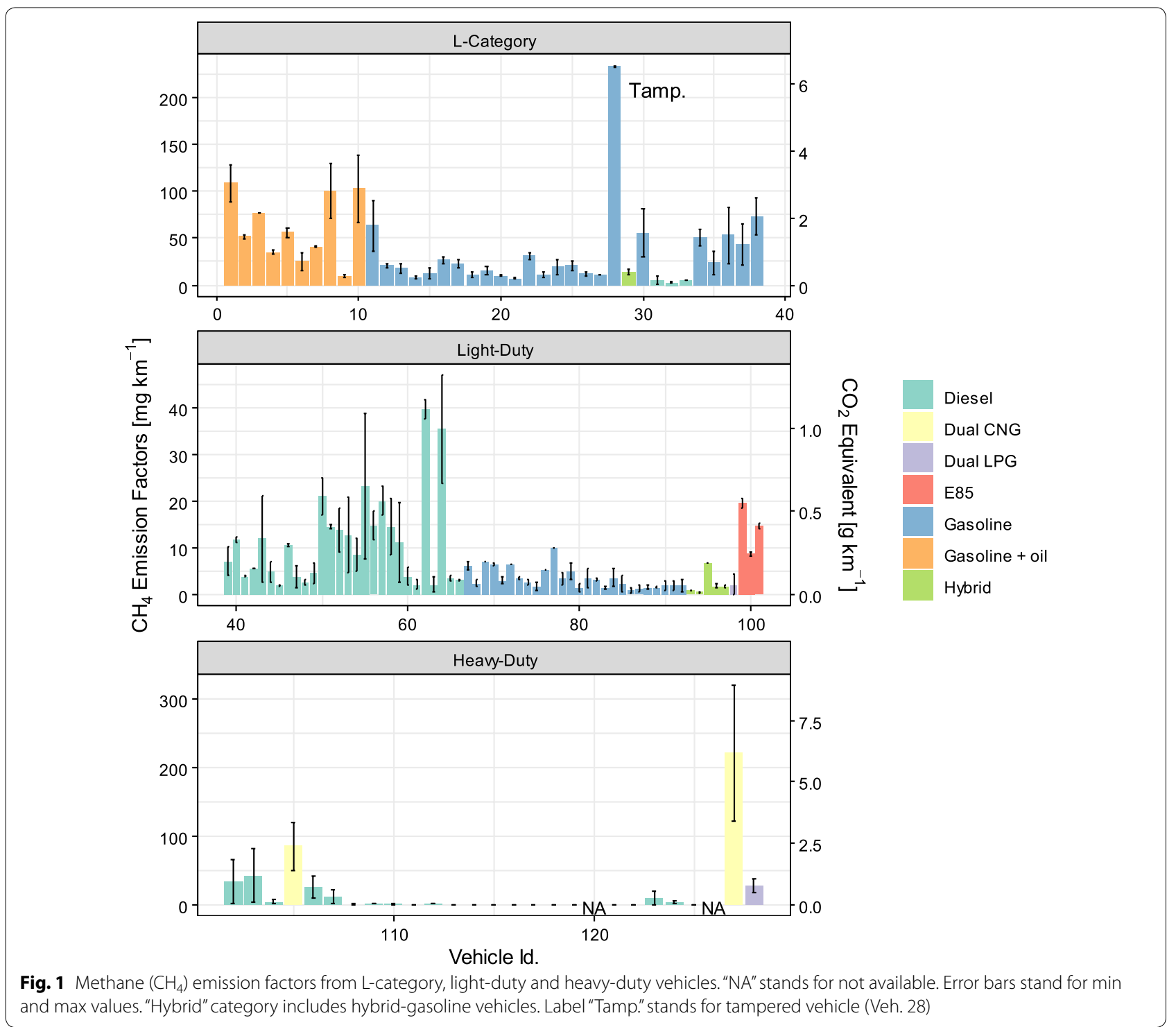

127, one dual LPG-Veh. 128), all the HDV were equipped with a diesel compression ignition engine. All diesel vehicles were associated to $\mathrm{CH}_{4}$ emission ranging from below the detection limit of the instruments to $42 \mathrm{mg} / \mathrm{km}$. Dual-fuel LPG/diesel vehicle emitted $28 \mathrm{mg} / \mathrm{km}$ of $\mathrm{CH}_{4}$. However, the dual-fuel CNG vehicles running with CNG were the highest emitter of $\mathrm{CH}_{4}$, with tailpipe emission ranging from 50 to $120 \mathrm{mg} / \mathrm{km}$, and from 122 to $319 \mathrm{mg} /$ $\mathrm{km}$ for Veh. 105 (CNG/gasoline) and Veh. 127 (CNG/diesel), respectively. It has to be mentioned that two HDV vehicles Euro V and Euro VI (Veh. 120 and 126) were only tested on-road without instrumentation capable to measure $\mathrm{CH}_{4}$.

\section{$\mathrm{N}_{2} \mathrm{O}$ emission factors}

Nitrous oxide emissions from the fleet of vehicles studied are presented in Fig. 2. The average emissions of $\mathrm{N}_{2} \mathrm{O}$ from the L-cat ranged from below the detection limit of the instruments to $4.5 \mathrm{mg} / \mathrm{km}$. Two-stroke vehicles, fueled with a mixture of gasoline and lubricant oil (Veh. 1-10), displayed $\mathrm{N}_{2} \mathrm{O}$ emissions mostly lower than $1 \mathrm{mg} / \mathrm{km}$, apart from Veh. 9 which displayed on average $2.4 \mathrm{mg} / \mathrm{km}$. Vehicles fueled with gasoline only (Veh. 11-30 and 34-38) and hybrid-gasoline vehicle (Veh. 29) displayed $\mathrm{N}_{2} \mathrm{O}$ emissions ranging from 0.1 to $4.5 \mathrm{mg} / \mathrm{km}$. The tampered vehicle (Veh. 28) displaying abnormally high level of $\mathrm{CH}_{4}$ was not associated to equivalently high emission of $\mathrm{N}_{2} \mathrm{O}(1.5 \mathrm{mg} / \mathrm{km})$. 


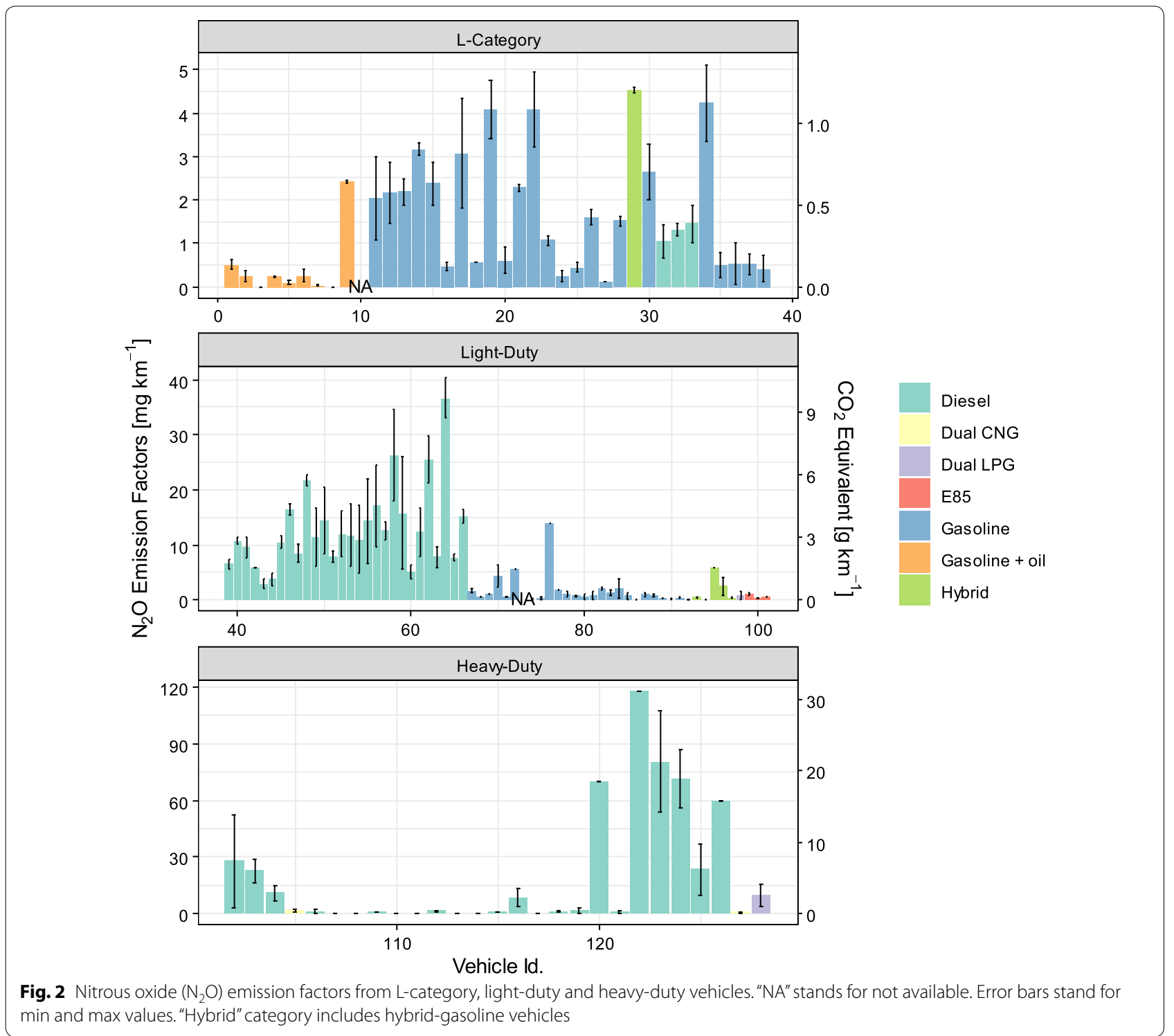

Regarding the vehicles fueled with diesel (Veh. 31-33), the average $\mathrm{N}_{2} \mathrm{O}$ emissions were between 1 and $1.4 \mathrm{mg} /$ $\mathrm{km}$.

Nitrous oxide emissions from the LDV ranged from 0.1 to $37 \mathrm{mg} / \mathrm{km}$, with gasoline and hybrid vehicles (tested in charge sustaining mode) emitting between 0.1 and $14 \mathrm{mg} / \mathrm{km}$, and diesel vehicles emitting between 3 and $37 \mathrm{mg} / \mathrm{km}$. The three vehicles fueled with a mixture of gasoline with E85 (Veh. 99-101) displayed slightly lower $\mathrm{N}_{2} \mathrm{O}$ emissions compared to those from the gasoline vehicles, with values lower than $1.5 \mathrm{mg} /$ $\mathrm{km}$, while the dual-fuel LPG/gasoline vehicle (Veh. 98) had an average $\mathrm{N}_{2} \mathrm{O}$ emission of $1 \mathrm{mg} / \mathrm{km}$.

Nitrous oxide emissions from HDV ranged from below the detection limit of the instruments to up to $118 \mathrm{mg} / \mathrm{km}$. The distance-based $\mathrm{N}_{2} \mathrm{O}$ emissions obtained with the dual-fuel LPG/diesel vehicle was $9.5 \mathrm{mg} / \mathrm{km}$. The two CNG vehicles had average $\mathrm{N}_{2} \mathrm{O}$ emissions of 1.4 and $0.4 \mathrm{mg} / \mathrm{km}$ (Veh. 105 and 127, respectively). It has to be noticed the significant $\mathrm{N}_{2} \mathrm{O}$ emissions obtained from the two HDV vehicles Euro V and Euro VI tested on the road (Veh. 120 and 126), with values ranging from 60 to $70 \mathrm{mg} / \mathrm{km}$. These results are presented in more details in the literature ([46]; [52]). For the HDV tested over ISC cycles (reproducing onroad cycles), no systematic difference was found on the $\mathrm{N}_{2} \mathrm{O}$ emissions when compared with the results obtained with the standard laboratory driving cycle (ETC or WHVC). 


\section{$\mathrm{CO}_{2}$ emission factors}

Carbon dioxide emissions from the studied fleet are presented in Fig. 3. The average emissions of $\mathrm{CO}_{2}$ from the $\mathrm{L}$-cat ranged from 27 to $263 \mathrm{~g} / \mathrm{km}$. Mopeds fueled with a mixture of gasoline and lubricant oil (Veh. 1-10) displayed $\mathrm{CO}_{2}$ emissions from 27 to $64 \mathrm{~g} / \mathrm{km}$. Vehicles fueled with gasoline only (Veh. 11-30 and 34-38) and hybrid-gasoline vehicle (Veh. 29) displayed average $\mathrm{CO}_{2}$ emissions ranging from 39 to $263 \mathrm{~g} / \mathrm{km}$, with the highest emitters among the heavy quadricycle and high-performance motorcycles. Regarding the vehicles fueled with diesel (Veh. 31-33), the $\mathrm{CO}_{2}$ emissions ranged between 89 and $112 \mathrm{~g} / \mathrm{km}$.

Carbon dioxide emissions from the LDV ranged from 53 to $315 \mathrm{~g} / \mathrm{km}$, with gasoline emitting between 112 and $294 \mathrm{~g} / \mathrm{km}$, gasoline hybrid vehicles (tested in charge sustaining mode) emitting between 53 and $133 \mathrm{~g} / \mathrm{km}$ and diesel vehicles emitting between 105 and $315 \mathrm{~g} / \mathrm{km}$. Carbon dioxide emissions from the LDV ranged from 53 to $315 \mathrm{~g} / \mathrm{km}(144 \pm 41 \mathrm{~g} / \mathrm{km}$-mean \pm one standard deviation), with gasoline emitting between 112 and $294 \mathrm{~g} /$ $\mathrm{km}(143 \pm 36 \mathrm{~g} / \mathrm{km})$, gasoline hybrid vehicles (tested in charge sustaining mode) emitting between 53 and $133 \mathrm{~g} /$ $\mathrm{km}(92 \pm 30 \mathrm{~g} / \mathrm{km})$ and diesel vehicles emitting between 105 and $315 \mathrm{~g} / \mathrm{km}(157 \pm 48 \mathrm{~g} / \mathrm{km})$.

Although the average $\mathrm{CO}_{2}$ emissions of diesel vehicles were higher relative to average $\mathrm{CO}_{2}$ emissions of gasoline vehicles, it has to be noted that the characteristics of the vehicles included in the two groups were not comparable. For the diesel group, the average engine capacity was ca $2.0 \mathrm{l}$ (with values ranging from 1.3 to $3.0 \mathrm{l}$ ), and the

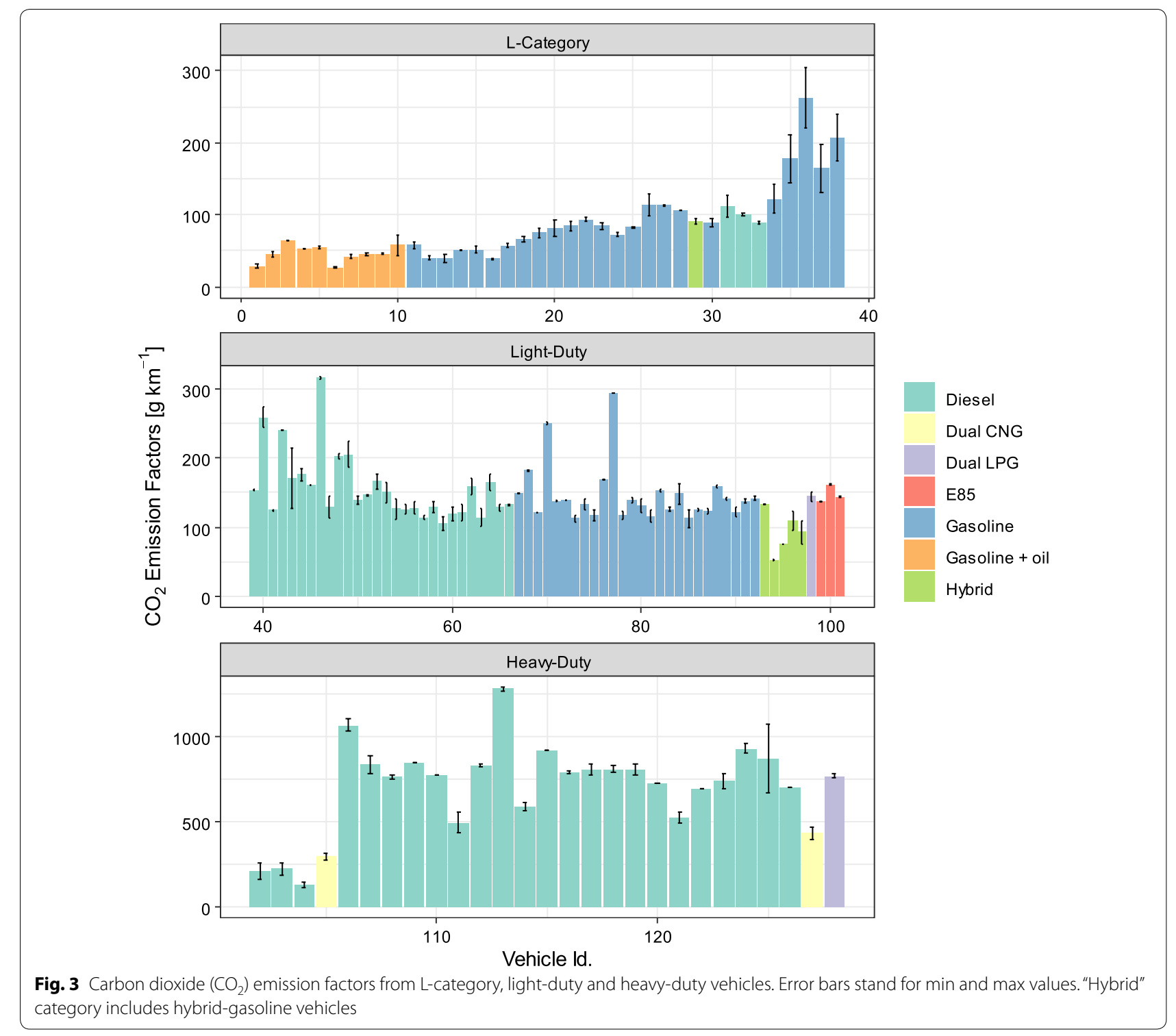


average power was $110 \mathrm{~kW}$ (with values ranging from 55 to $195 \mathrm{~kW}$ ). For the gasoline group, these values were lower compared to the diesel group, with average engine capacity of ca $1.3 \mathrm{l}$ (with values ranging from 0.9 to $2 \mathrm{l}$ ), and the average power of $80 \mathrm{~kW}$ (with values ranging from 51 to $155 \mathrm{~kW}$ ). More details on the $\mathrm{CO}_{2}$ emissions of some of the LDV vehicles included here can be found in the literature [65]. The three vehicles fueled with a mixture of gasoline with $85 \% \mathrm{v} / \mathrm{v}$ ethanol (E85) (Veh. 99-101) displayed $\mathrm{CO}_{2}$ emissions ranging from 137 and $162 \mathrm{~g} / \mathrm{km}$. Average $\mathrm{CO}_{2}$ emissions from $\mathrm{HDV}$ ranged from 129 to up to $1300 \mathrm{~g} / \mathrm{km}$.

\section{Discussion}

\section{Comparison of data with the literature values}

Unlike regulated emissions, very few data related to the unregulated GHG emissions from L-cat are available in the literature. In particular, one high-performance motorcycle was a tampered vehicle (tailpipe replaced with an aftermarket sport one-Veh. 28). The effect of tampering on nine two-wheelers was investigated by Zardini et al. [70], and it was found that tampered vehicles were associated to an increase of factor of up to 27 for what regards hydrocarbons emissions, considering the original manufacturer configuration as a baseline. However, the effect of tampering was not visible on the $\mathrm{N}_{2} \mathrm{O}$ emission of this vehicle. This finding is in good agreement with the study from Zardini et al. [70] where the effect of the removal of the two-way catalyst did not influence the emitted nitrogen containing species, but mostly THC and CO.

The large amount of $\mathrm{CH}_{4}$ emitted by the Euro II dualfuel CNG truck was in the same order of magnitude as the average $\mathrm{CH}_{4}$ emissions from $\mathrm{CNG}$ vehicles reported in the extended study conducted by Dalianis et al. [12] This level of emissions was also in good agreement with the emission factors from another study with a truck equipped with an Euro V compliant CNG engine (ca. $200 \mathrm{mg} / \mathrm{km}$ over equivalent chassis dynamometer tests) [36]. However, these values remained lower than the values from three urban buses equipped with CNG engine for which $6.3 \mathrm{~g} / \mathrm{km}$ average $\mathrm{CH}_{4}$ emission was reported [35]. These $\mathrm{CH}_{4}$ emissions were also lower than the average emission reported by Thiruvengadam et al. [60] from three tractors equipped with natural gas engine and TWC $(1.1 \mathrm{~g} / \mathrm{km})$.

Data related to the $\mathrm{N}_{2} \mathrm{O}$ emission factors from modern LDV are also very scarce. Distance-based $\mathrm{N}_{2} \mathrm{O}$ emission factors obtained for modern gasoline LDV (Euro 5 and Euro 6) were in good agreement with those obtained from a US type-approved super ultra-low emission vehicle (SULEV) compliant LDV, whose $\mathrm{N}_{2} \mathrm{O}$ emission were found to be lower than $6 \mathrm{mg} / \mathrm{km} \mathrm{[3].} \mathrm{N}_{2} \mathrm{O}$ from the gasoline LDV measured were also found in the same order of magnitude compared to another studies, such as one on plug-in hybrid vehicle [53], and one including new and aged gasoline Tier 2 standard vehicles analyzed at the Environmental Canada and California Air Resources Board between 2001 and 2007 [34]. However, the same study reported average values of 4 and $6 \mathrm{mg} / \mathrm{km}$ for diesel vehicles complying with Euro 3 and Euro 4 standards, respectively, thus substantially lower than values reported for Euro 5 and Euro 6 diesel LDV included in the present study. Lang et al. [44] reported $\mathrm{N}_{2} \mathrm{O}$ distancebased emission factors from gasoline LDV within a range from 45 to $21 \mathrm{mg} / \mathrm{km}$, decreasing with the increase of the standard stringency. $\mathrm{N}_{2} \mathrm{O}$ from four diesel Euro $6 \mathrm{~b}$ vehicles (station wagon and van) were reported with values of up to $7 \mathrm{mg} / \mathrm{km}$ and $1 \mathrm{mg} / \mathrm{km}$ for vehicles tested in laboratory and on-road, respectively [66]. In a study from Giechaskiel et al. [33], it was found that retrofitting a Euro $5 b$ vehicle with a SCR system increased the $\mathrm{N}_{2} \mathrm{O}$ emissions on average about $16 \mathrm{mg} / \mathrm{km}$, which represented 2-3 times higher emissions compared to the values obtained with the same non-retrofitted vehicle.

In the data reported by Thiruvengadam et al. [60], $\mathrm{N}_{2} \mathrm{O}$ emissions from 2 US-EPA 2010 emissions compliant trucks without SCR system were found ranging from 23 to $38 \mathrm{mg} / \mathrm{km}$, thus in line with the data reported for the Euro VI HDV of this study. In the study carried out by Graham et al. [35], two diesel heavy-duty vehicles certified under the California 2004 Tier 1 emission standards were tested in diesel and LPG configurations. Nitrous oxide emissions obtained from the LPG mode was found in a slightly higher level compared with this study, with an average of $20 \mathrm{mg} / \mathrm{km}$. However, with an average of $14 \mathrm{mg} / \mathrm{km}$, emissions from the two heavy-duty vehicles tested in the study of Graham et al. were found in the same range of those from the Euro V HDV included in this study.

\section{Impact of $\mathrm{GHG}$ emissions on $\mathrm{CO}_{2}$-related policy}

Considering the GWP defined by the IPCC, it was found that the reported $\mathrm{CH}_{4}$ and $\mathrm{N}_{2} \mathrm{O}$ tailpipe emissions from the transport sector may reach up to $32 \mathrm{~g} / \mathrm{km}$ of $\mathrm{CO}_{2}$-equivalent $\left(\mathrm{CO}_{2}\right.$-eq.g-Figs. 1 and 2, right scales). While the methane emissions were in order of magnitude of up to few $\mathrm{CO}_{2}$-eq.g for the L-cat and the HDV fueled with CNG, the nitrous oxide emissions ranged from few $\mathrm{CO}_{2}$-eq.g to up to several tens of $\mathrm{CO}_{2}$-eq.g for the diesel LDV and HDV, respectively.

The $\mathrm{CO}_{2}$-eq.g from $\mathrm{CH}_{4}$ and $\mathrm{N}_{2} \mathrm{O}$ emissions expressed in share, considering the tailpipe $\mathrm{CO}_{2}$ emissions of the vehicles as a baseline, are presented in Fig. 4. Among all vehicles tested, the highest level of $\mathrm{CO}_{2}$-eq.g derived from methane was found for two-stroke L-cat (range from 0.5 to $11 \%$ of the tailpipe $\mathrm{CO}_{2}$ emitted), gasoline 


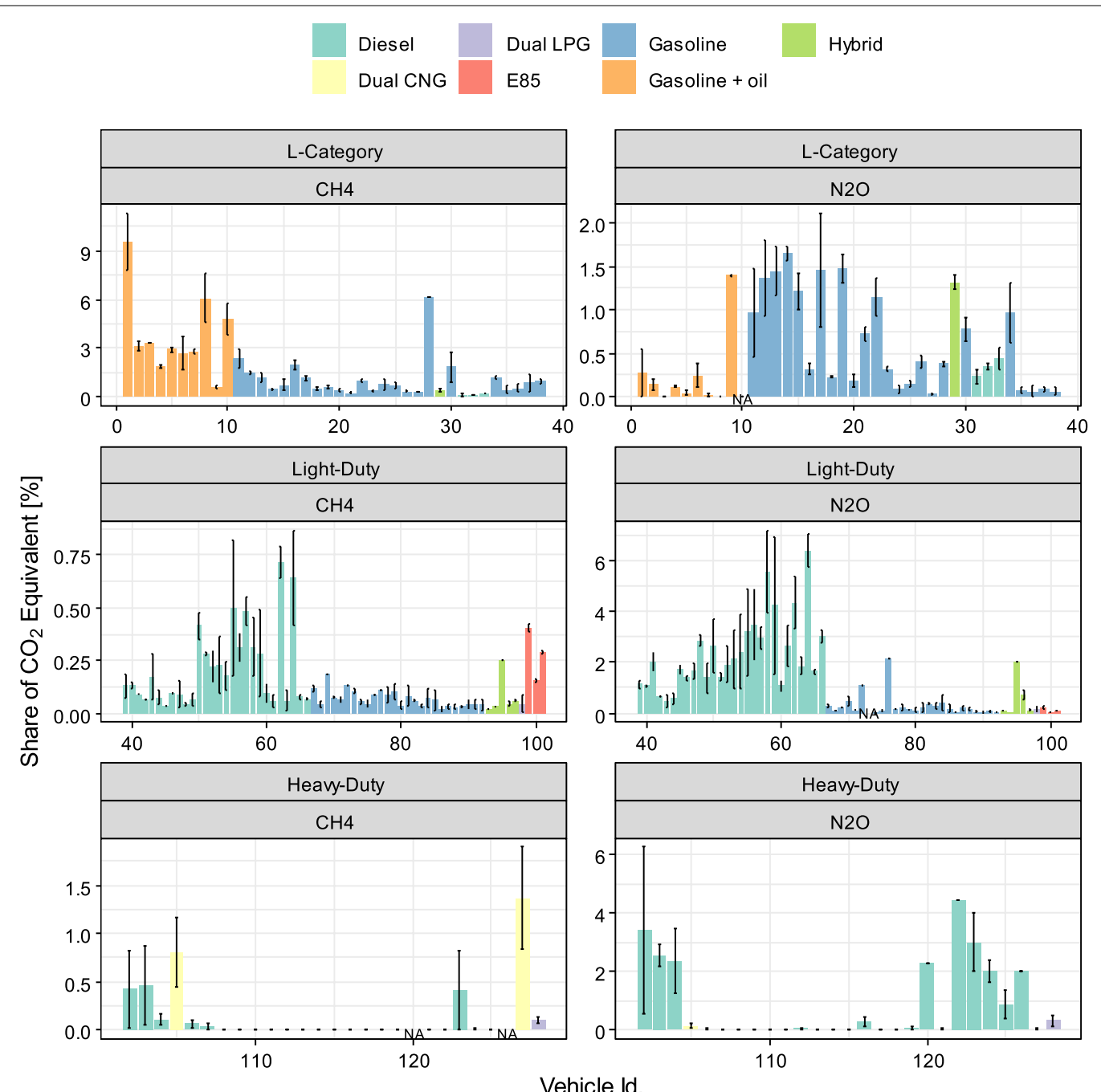

Vehicle ld.

Fig. 4 Share of $\mathrm{CO}_{2}$ from methane and nitrous oxide emissions, considering direct $\mathrm{CO}_{2}$ emissions from L-category, light-duty and heavy-duty vehicles as a baseline. "NA" stands for not available. Error bars stand for min and max values. "Hybrid" category includes hybrid-gasoline vehicles

L-cat (range from 0.2 to $3 \%$ of the tailpipe $\mathrm{CO}_{2}$ emittedtampered Veh. 28 excluded) and for two HDV (Veh. 105 and 127 fueled with CNG: from 1 to $2 \%$ ). The range of the share of $\mathrm{CO}_{2}$-eq.g from methane measured for the LDV was in line with data from older vehicles available in the literature [47]. Regarding the $\mathrm{CO}_{2}$-eq.g derived from nitrous oxide, the highest shares were observed for L-cat with the gasoline and gasoline hybrid vehicles (range from less than 0.1 to $2 \%$ ). However, as regards LDV and $\mathrm{HDV}$, the highest shares of $\mathrm{CO}_{2}$-eq.g from nitrous oxide were associated to diesel vehicles, with range from 0.2 to $7.2 \%$ (LDV) and from less than 0.1 to $6.3 \%$ (HDV).

On average, modern LDV included in this study displayed $\mathrm{N}_{2} \mathrm{O}$ emissions equivalent to $1.8 \mathrm{CO}_{2}$-eq.g, with some diesel LDV vehicles displaying more than $6 \mathrm{CO}_{2}$-eq.g. This level of emission was well above the threshold of $1 \mathrm{~g} / \mathrm{km} \mathrm{CO}_{2}$ defined in e.g. Eco-innovation scheme ([20]-see also "Background" section). Consequently, by taking out of the account current GHG emissions like $\mathrm{N}_{2} \mathrm{O}$, such efforts implemented to reduce tailpipe $\mathrm{CO}_{2}$ emission from LDV might be jeopardized.

\section{Effect of the fuel and engine technology on $\mathrm{CH}_{4}$ and $\mathrm{N}_{2} \mathrm{O}$ emissions from L-cat and LDV}

Table 2 presents the $\mathrm{CH}_{4}$ and $\mathrm{N}_{2} \mathrm{O}$ median emissions of the vehicle studied. The relationship between fuel/ engine technologies and GHGs tailpipe emissions of L-cat and LDV were investigated through multiple group comparisons. This statistical analysis was not carried out on the HDV as only three non-diesel vehicles were tested. Figure $5 \mathrm{a}$ displays the $\mathrm{CH}_{4}$ and $\mathrm{N}_{2} \mathrm{O}$ tailpipe emissions for the L-cat vehicles fueled with diesel, gasoline 
Table 2 Summary of the median emissions of $\mathrm{CH}_{4}$ and $\mathrm{N}_{2} \mathrm{O}$ from the vehicles tested

\begin{tabular}{|c|c|c|c|c|c|}
\hline Category & Fuel & Standard & $\begin{array}{l}\text { Number of vehicles } \\
\text { tested }\end{array}$ & $\mathrm{CH}_{4}(\mathrm{mg} / \mathrm{km})$ & $\mathrm{N}_{2} \mathrm{O}(\mathrm{mg} / \mathrm{km})$ \\
\hline \multirow[t]{4}{*}{ L-cat } & Gasoline + oil & Euro 1/2 & 10 & 53.6 & 0.2 \\
\hline & Gasoline & Euro 2/3/4 & 23 & 20.7 & 1.6 \\
\hline & Diesel & Euro 2 & 3 & 5.0 & 1.3 \\
\hline & Gasoline hybrid & Euro 3 & 1 & 13.7 & 4.5 \\
\hline \multirow[t]{10}{*}{ LDV } & Gasoline & Euro 5 & 2 & 4.8 & 3.1 \\
\hline & & Euro $6 \mathrm{~b} / \mathrm{c}$ & 13 & 3.2 & 0.9 \\
\hline & & Euro 6d-TEMP & 7 & 1.7 & 0.3 \\
\hline & Diesel & Euro 5 & 2 & 3.6 & 6.2 \\
\hline & & Euro $6 \mathrm{~b} / \mathrm{c}$ & 16 & 10.3 & 13.5 \\
\hline & & Euro 6d-TEMP & 5 & 3.6 & 15.2 \\
\hline & Gasoline hybrid & Euro 5 & 2 & 0.8 & 0.3 \\
\hline & & Euro $6 \mathrm{~b}$ & 2 & 4.5 & 3.2 \\
\hline & Flex-fuel (E85) & Euro 5 & 3 & 14.7 & 0.5 \\
\hline & Dual-LPG/Gasoline & Euro $6 b$ & 1 & 2.3 & 0.9 \\
\hline \multirow[t]{11}{*}{ LCV and HDV } & Diesel & Euro $3^{(*)}$ & 1 & 33.4 & 27.9 \\
\hline & & Euro $6 b^{(*)}$ & 2 & 23.6 & 16.8 \\
\hline & Dual-CNG/Gasoline & Euro $6 b^{(*)}$ & 1 & 84.8 & 1.4 \\
\hline & Diesel & Pre-Euro I & 1 & 25.8 & 1.1 \\
\hline & & Euro II & 5 & 1.6 & $<0.1$ \\
\hline & & Euro III & 1 & 0.3 & $<0.1$ \\
\hline & & Euro IV & 1 & 2.4 & 1.3 \\
\hline & & Euro V & 10 & 0.1 & 0.8 \\
\hline & & Euro VI & 5 & 1.8 & 71.4 \\
\hline & Dual-LPG/Diesel & Euro V & 1 & 27.9 & 9.5 \\
\hline & Dual-CNG/Diesel & Euro II & 1 & 220.8 & 0.4 \\
\hline
\end{tabular}

(*) Light commercial vehicles ( 4 in total) are included in the HDV category. For the LDV, results were calculated from the WLTC only. “Hybrid” category includes hybridgasoline vehicles

and gasoline with lubricant oil (2-stroke mopeds with $25 \mathrm{~km} / \mathrm{h}$ or $45 \mathrm{~km} / \mathrm{h}$ maximum speed, belonging to the L1e sub-category). For the hypothesis testing, multiple pairwise comparisons of each group were achieved. As discussed before, the tampered L-cat with Id.28 was removed prior to the analysis.

The median emissions of $\mathrm{CH}_{4}$ were 5.0, 20.7 and $53.6 \mathrm{mg} / \mathrm{km}$ for L-cat fueled with diesel, gasoline and gasoline with oil, respectively (Table 2, Fig. 5a-left panel). It was found that vehicles fueled with gasoline and lubricant oil (two-stroke mopeds) emitted significantly more $\mathrm{CH}_{4}$ than the vehicles fueled with gasoline only and diesel ( $p$ value of 0.007 and 0.007 , respectively). The difference was confirmed also by comparing mopeds only. The unburnt lubricant significantly contributed to higher $\mathrm{CH}_{4}$ (and THC). Comparing mopeds and the rest vehicles, the high $\mathrm{CH}_{4}$ of moped might be explained by the less sophisticated after-treatment system installed on them compared to the one installed on the other category of L-cat gasoline vehicles. In addition, the vehicles fueled with only gasoline (four-stroke mopeds, light to high-performance motorcycles, and quadricycles) emitted significantly more $\mathrm{CH}_{4}$ compared to the vehicle fueled with diesel (commercial tricycles and light quadrimobiles) ( $p$ value $=0.0008)$. The lower engine out emissions and the presence of a DOC on two of the three diesel vehicles might explain this trend. However, it has to be kept in mind that the sample size of L-cat diesel vehicles was very small (only three vehicles-Additional file 1: Table S1).

For what concerns the $\mathrm{N}_{2} \mathrm{O}$ emissions of L-cat, the median emissions were 1.3, 1.6 and $0.2 \mathrm{mg} / \mathrm{km}$ for vehicles fueled with diesel, gasoline and gasoline with oil, respectively (Table 2, Fig. 5a-right panel). It was found that vehicles fueled with gasoline emitted significantly more $\mathrm{N}_{2} \mathrm{O}$ than the vehicles fueled with gasoline and lubricant oil ( $p$ value $=0.0014)$. This difference was confirmed also when comparing only mopeds with and without lubricant at the fuel. This trend could be explained by due to the presence of TWC among the vehicles fueled with gasoline. However, the absolute levels and 
a

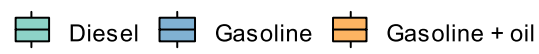
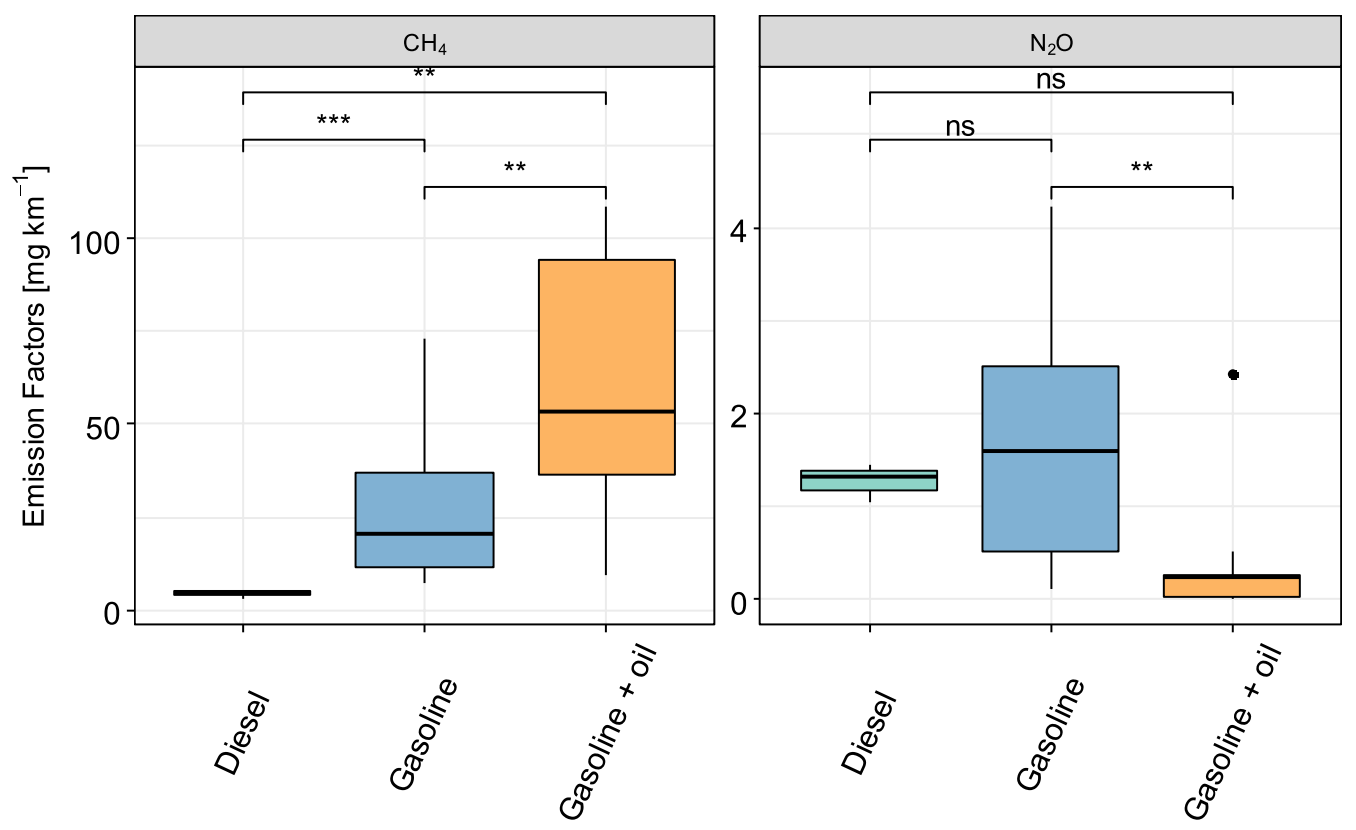

b

自 Diesel 島 E85 自 Gasoline 鸟 Hybrid
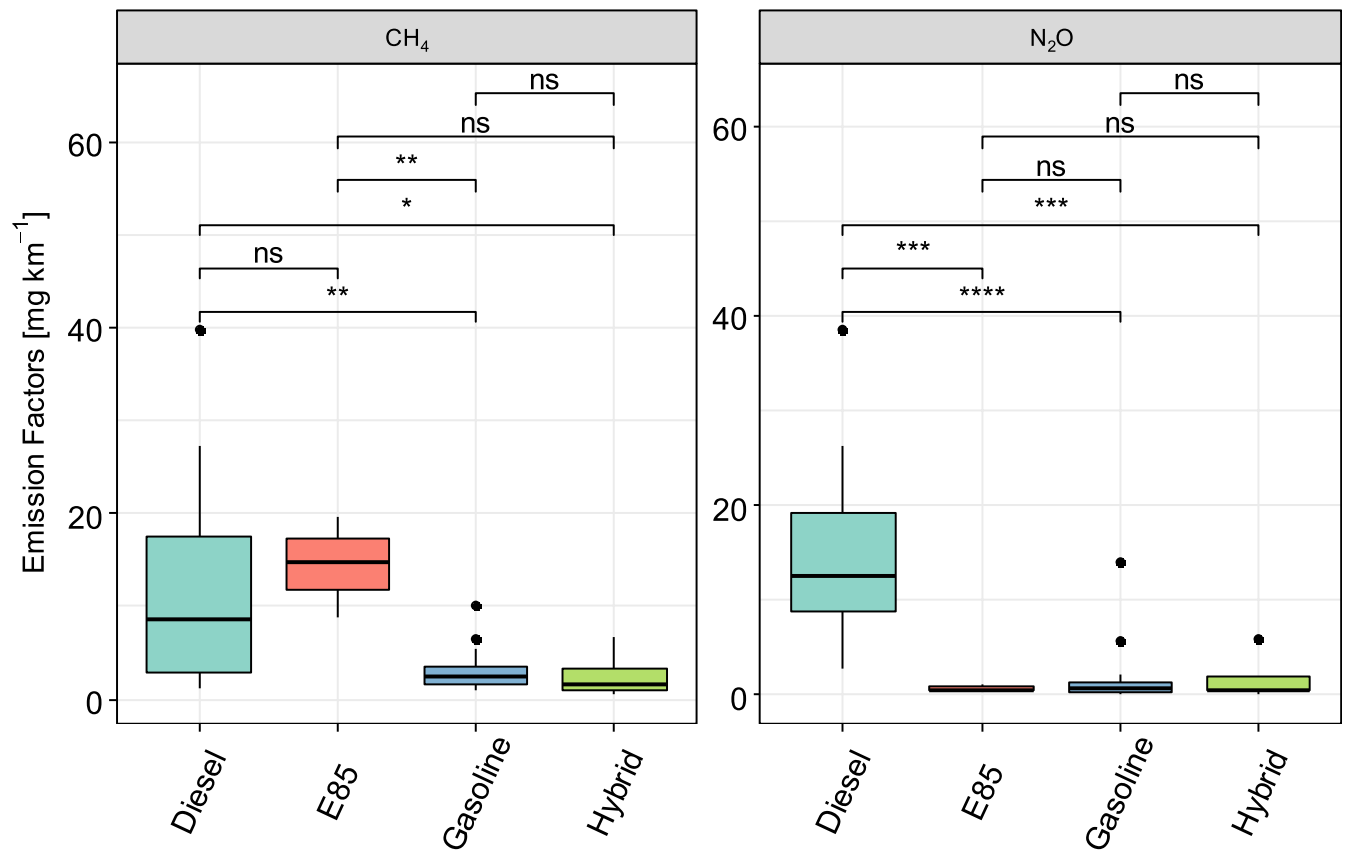

Fig. 5 Effect of fuel/engine technology on the $\mathrm{CH}_{4}$ and $\mathrm{N}_{2} \mathrm{O}$ average emissions from L-category (top panels-a) and light-duty (bottom panels-b) vehicles. "Hybrid" category includes hybrid-gasoline vehicles. Kruskal-Wallis statistical test with ns: $p>0.05,{ }^{*} p \leq 0.05,{ }^{* *} p \leq 0.01,{ }^{* * *} p \leq 0.001$, **** $p \leq 0.0001$ 
differences were very low $(<2 \mathrm{mg} / \mathrm{km})$. No significant difference was found for the other comparisons.

The latest legislative development related to the L-cat included the revision of type approval of mopeds and motorcycles, with the implementation of the Euro 4 (enforced period 2016-2018) and Euro 5 (being mandatory for new types of vehicles as of January 2020) standards. With lower emission limits, and more realistic driving cycles, the effect of the proposed standards on the tailpipe emissions of GHGs from L-cat may be substantial. The two-stroke mopeds (fueled with mixture of gasoline and lubricant oil) will have to undertake a significant effort to shift to the new regulated limits [11]. The upcoming Euro 5 standard will probably be associated with a larger share of four-stroke and a net decrease of the two-stroke mopeds (fueled with gasoline and lubricant oil) for which it will be technically challenging, and not economically convenient, to comply with the new limits. Consequently, with the implementation of the new standard, it can be expected a substantial reduction of the $\mathrm{CH}_{4}$ emissions emitted by the L1e vehicles. However, considering that the total fleet of L-cat in EU was composed of ca. $14 \mathrm{M}$ of mopeds (L1e) in 2015, with a share of $2 \%$ of new registration per year $(320,000$ new vehicles in 2016 according to the European Association of Motorcycle Manufacturers [1]), the effect of the Euro 5 standard on the $\mathrm{CH}_{4}$ emissions from L-cat will be visible in several years from now.

The relationship between fuel/engine technology and GHG tailpipe emissions from LDV is presented in Fig. 5B. The median emissions of $\mathrm{CH}_{4}$ were 14.7, 8.5, 2.4 and $1.6 \mathrm{mg} / \mathrm{km}$ for LDV fueled with E85, diesel, gasoline and for the hybrid vehicles, respectively. Vehicles fueled with diesel emitted significantly more $\mathrm{CH}_{4}$ than the vehicles fueled with gasoline and the hybrid vehicles ( $p$ value of 0.003 and 0.03 , respectively). This finding, in connection with the after-treatment devices, is discussed later in this section. In addition, the flex-fuel vehicles fueled with E85 emitted significantly more $\mathrm{CH}_{4}$ compared to the vehicle fueled with gasoline ( $p$ value $=0.002)$. Higher methane emission from relatively old flex-fuel vehicles (Tier 0 US standard) was already reported in the literature [43]. In addition, chassis dynamometer studies on a Euro 4 and Euro 5 flex-fuel vehicles, reported also more $\mathrm{CH}_{4}$ emissions when fuel with $85 \%$ ethanol was used $[9,51,56,58]$. As explained in that study, $\mathrm{CH}_{4}$ emissions were highly related to the cold start of the vehicles (together with unburned hydrocarbons), and fuel with high ethanol content may produce more water at the catalyst surface, making $\mathrm{CH}_{4}$ oxidation difficult. These two facts may explain a longer period before catalyst light-off, and thus, the greater methane emissions observed with E85 compared to gasoline fuel.
Median emissions of $\mathrm{N}_{2} \mathrm{O}$ were 12.6, 0.7, 0.5 and $0.5 \mathrm{mg} / \mathrm{km}$ for LDV fueled with diesel, gasoline, E85 and for the hybrid vehicles, respectively (Fig. 5b). It was found that vehicles fueled with diesel emitted significantly more $\mathrm{N}_{2} \mathrm{O}$ than the vehicles fueled with gasoline, E85 and the hybrid vehicles ( $p$ value of $4 \cdot 10^{-10}, 0.0008$ and 0.0002 , respectively). These findings are consistent with the results obtained over on-road tests where $\mathrm{N}_{2} \mathrm{O}$ emissions from two LDV gasoline were found non-detectable while two LDV diesel where emitting up to $27 \mathrm{mg} / \mathrm{km}$ [54]. High $\mathrm{N}_{2} \mathrm{O}$ emissions from diesel fueled LDV (ca. 20 times more than gasoline fueled LDV) were investigated more in details considering the type of catalyst implemented on diesel vehicles (see Additional file 1: Table S2).

Figure 6 presents the effect of after-treatment systems on the Diesel LDV GHG emissions. In terms of $\mathrm{CH}_{4}$ tailpipe emissions, Euro 6 vehicles equipped with LNT/ NSC systems emitted significantly more than Euro 6 vehicles equipped with SCR only ( $p$ value $=0.0002$ ), as well as than Euro 5 vehicles equipped with DOC only $(p$ value $=0.03)$. Such differences might be explained by the operational principle of the LNT/NSC systems which work as active NOx absorbers. These systems store NOx during lean air-to-fuel ratio operation of the vehicles. Then, through brief regenerating periods, NOx is released and catalytically reduced to nitrogen during rich air-to-fuel ratio. Such regenerating periods are more prone to release $\mathrm{CO}$ and hydrocarbons (including $\mathrm{CH}_{4}$ ) and could explain the higher $\mathrm{CH}_{4}$ emissions associated to LNT/NSC systems.

In terms of $\mathrm{N}_{2} \mathrm{O}$ tailpipe emissions, it appeared that vehicles equipped with LNT/NSC or SCR after-treatment systems were associated to more emissions than Euro 5 ones equipped with DOC, as well as Euro 6 ones equipped with SCR only (18.4, 6.2 and $12.8 \mathrm{mg} / \mathrm{km}$, respectively). However, these differences were not found significant according to the statistical test applied ( $p$ value $>0.05)$. The statistical inferences were based on a small sample composed of 20 vehicles, but these findings can be considered as a good insight of the effect of aftertreatment systems on the GHG emissions.

\section{Trend along with emission standards}

Table 2 and Fig. 7a present the relationship between the emission standard and the $\mathrm{CH}_{4}$ and $\mathrm{N}_{2} \mathrm{O}$ emissions from LDV. On the tailpipe methane emissions, for diesel, gasoline and hybrid vehicles, no significant effect was found for the shifting from Euro 5 to Euro 6b standards. Regarding the shifting from Euro $6 \mathrm{~b}$ to Euro 6d-TEMP standards, only a significant reduction of the $\mathrm{CH}_{4}$ emissions of the gasoline vehicles was found ( $p$ value: 0.03 ). Regarding the $\mathrm{N}_{2} \mathrm{O}$ tailpipe emissions, no statistically significant difference was found on the diesel, gasoline and hybrid 


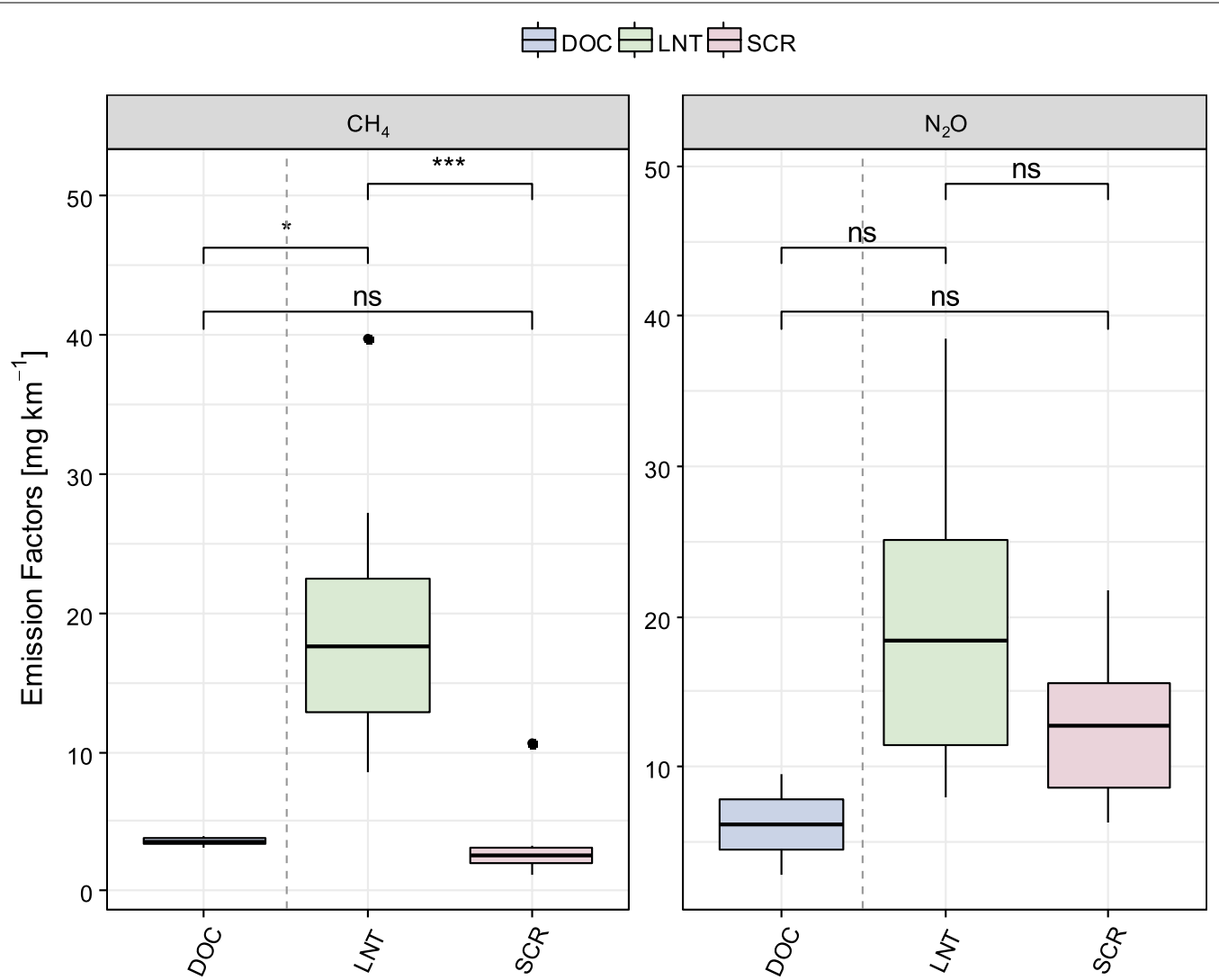

Fig. 6 Effect of after-treatment system on the $\mathrm{CH}_{4}$ and $\mathrm{N}_{2} \mathrm{O}$ average emissions from diesel light-duty vehicles. Kruskal-Wallis statistical test with ns: $p>0.05,{ }^{*} p \leq 0.05,{ }^{* *} p \leq 0.01,{ }^{* * *} p \leq 0.001,{ }^{* * *} p \leq 0.0001$

vehicles, with the shift from the Euro 5 to the Euro 6b, and neither with the shift from the Euro $6 \mathrm{~b}$ to the Euro $6 \mathrm{~d}$-Temp. However, for the diesel vehicles, it appeared that the median emissions of $\mathrm{N}_{2} \mathrm{O}$ tended to increase together with the standard (median emissions of 6.2, 13.5 and 15.2 for Euro 5b, Euro 6b and Euro 6d-TEMP, respectively). For diesel LDV, transition from Euro 5 to Euro 6 standard came together with a sharp reduction of the NOx standard (from 180 to $80 \mathrm{mg} / \mathrm{km}$, respectively). To comply with this more stringent limit, existing technology designed to reduce NOx engine out emission, like the exhaust gas recirculation (EGR), has to be complemented with additional one, such as LNT/NSC and SCR. As described in the previous section, these after-treatment technologies were associated to higher $\mathrm{N}_{2} \mathrm{O}$ emission compared to the technology implemented in Euro 5 (only DOC) [32, 33]. The same occurred for the HDV, where tailpipe $\mathrm{N}_{2} \mathrm{O}$ emissions were found significantly higher for vehicles complying with Euro VI compared to those complying with Euro V standard ( $p$ value: 0.004 , see Fig. 7b). Unlike for the LDV, it has to be noted that HDV were largely equipped with SCR after-treatment technology to comply with NOx limit defined in Euro V standard. The Euro VI defined emission limit of $10 \mathrm{ppm}$ for $\mathrm{NH}_{3}$, calculated as an average concentration obtained over the World Harmonized Transient Cycle (WHTC) and Steady-State Cycle (WHSC) for heavy-duty engines [21]. This provision together with a decrease of ca. 4-5fold of the NOx limits implied for HDV after-treatment a more intensive use of the SCR and also the complement with ammonia oxidation catalyst (AMOX). Veh. 126 included in this test fleet was a Euro VI compliant heavy-duty vehicle equipped with an AMOX. On-road $\mathrm{N}_{2} \mathrm{O}$ emissions from this truck was already described by the authors in the literature [46]. In summary, this study showed that based on the Engine Control Unit (ECU) signals recorded, $\mathrm{N}_{2} \mathrm{O}$ peak emissions were related to the injection of urea in the SCR. Association of substantial nitrous oxide emissions with the use of SCR after-treatment system in HDV was also reported in the test bench study from Borillo et al. [6]. In this test campaign, significantly greater $\mathrm{N}_{2} \mathrm{O}$ emissions were associated to a Euro $\mathrm{V}$ engine equipped with and SCR after-treatment system, compared to the same engine with SCR disabled ( $44 \mathrm{mg}$ / $\mathrm{kWh}$ and $13 \mathrm{mg} / \mathrm{kWh}$, respectively). Substantial $\mathrm{N}_{2} \mathrm{O}$ emissions from Euro V and Euro VI engines equipped 
a
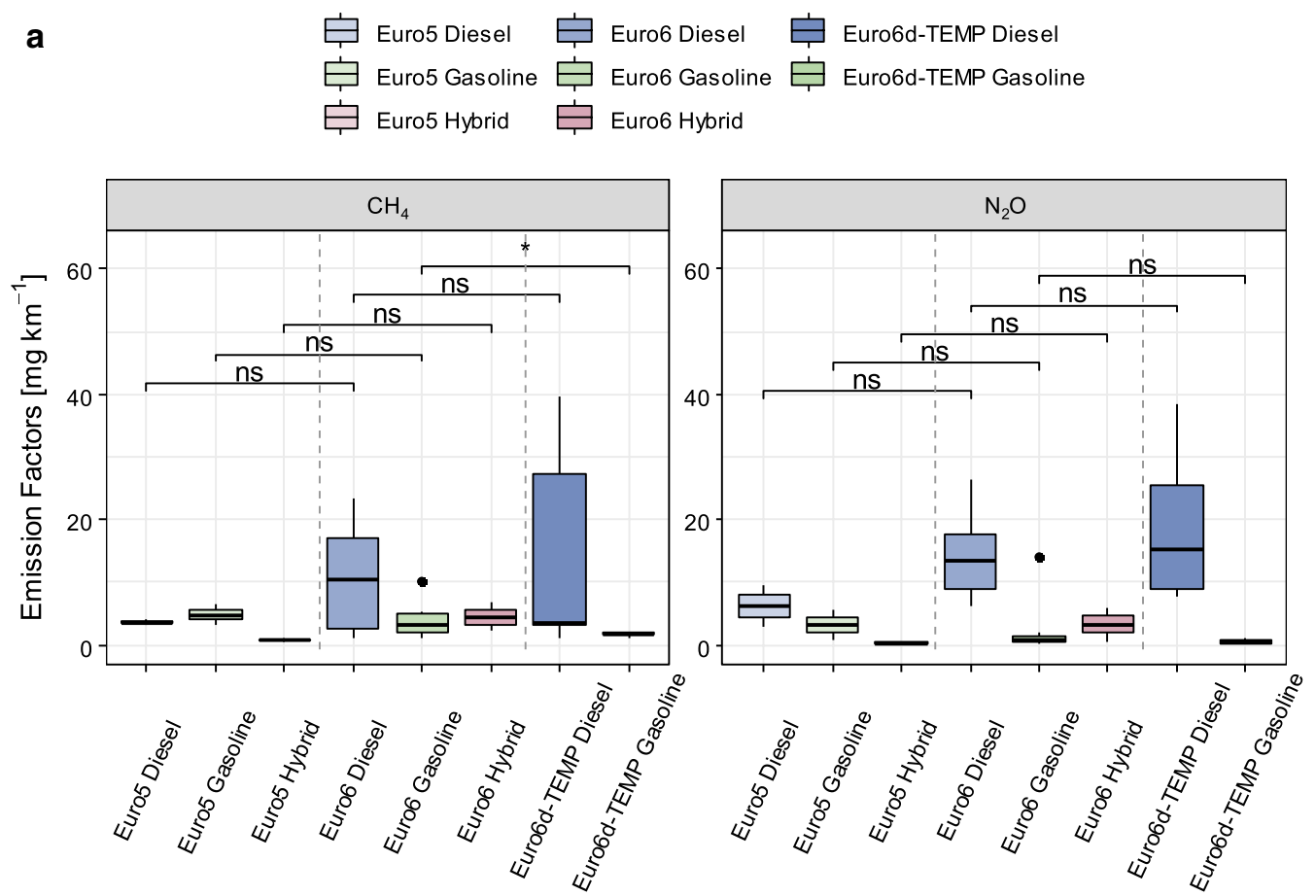

b
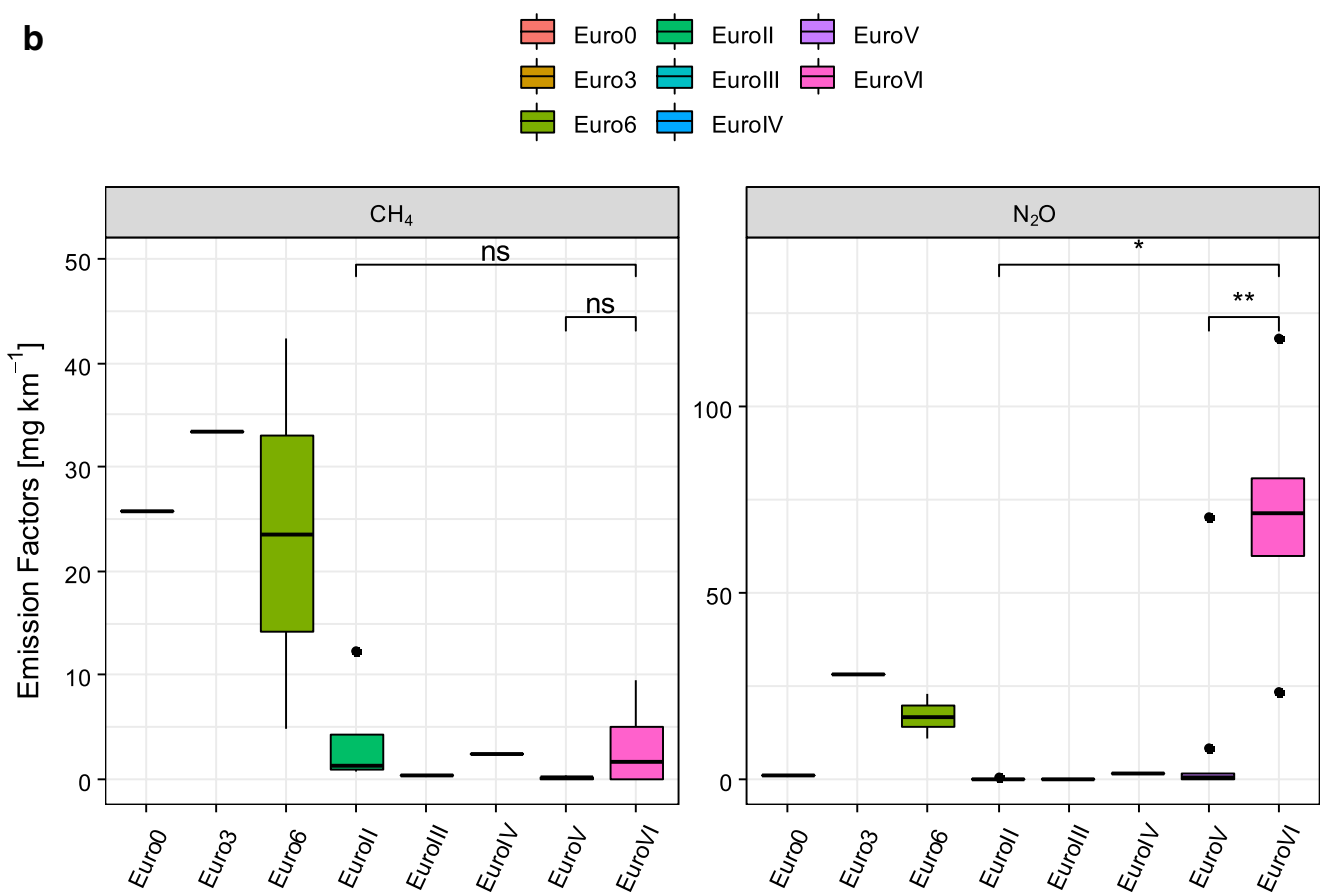

Fig. 7 Effect of Euro standards on the $\mathrm{CH}_{4}$ and $\mathrm{N}_{2} \mathrm{O}$ average emissions from light-duty (top panels-a) and diesel heavy-duty (bottom panels-b) vehicles. "Hybrid" category includes hybrid-gasoline vehicles. Horizontal lines stand for the unique values from group composed of one vehicle only. Kruskal-Wallis statistical test with ns: $p>0.05,{ }^{*} p \leq 0.05,{ }^{* *} p \leq 0.01,{ }^{* * *} p \leq 0.001,{ }^{* * * *} p \leq 0.0001$ 
with SCR were also reported by Tadano et al.[59] and Giechaskiel et al.[31].

In the review from Wallington and Wiesen [67], the $\mathrm{N}_{2} \mathrm{O}$ emissions from global transport were expected to decrease, with a projection of $0.064 \mathrm{Tg} \mathrm{N}_{2} \mathrm{O}-\mathrm{N} /$ year by 2030. According to this study, with such value on-road transport would contribute to $60 \%$ of the total $\mathrm{N}_{2} \mathrm{O}$ emissions from global transport. However, that study assumed a decrease of emissions from light-duty vehicles together with the setting of new emission standards [67]. This projection was mostly based on the emission inventory from Graham et al., which included a majority of light-duty gasoline vehicles, belonging to standards up to Euro 4 [34]. Figure 8 gives a picture of the share of $\mathrm{CO}_{2}, \mathrm{~N}_{2} \mathrm{O}$ and $\mathrm{CH}_{4}$ emissions in the total GHG emissions of the fleet studied. The shares were calculated based on the total CO2-eq.g from these three compounds. Considering the findings from our study, and assuming a global implementation of the latest after-treatment technologies, it is likely that the contribution from on-road transport will increase to reach significantly more the $60 \%$ of the total $\mathrm{N}_{2} \mathrm{O}$ emissions from global transport by 2030 reported by Wallington and Wiesen [67]. In addition, this trend is not expected to change in coming years with the introduction of Worldwide harmonized Light vehicles Test Procedure (WLTP) and the complementary RealDriving Emissions (RDE) test. The major revision of EU legislation on the type approval of light-duty vehicles may likely be associated with both a broader implementation, and a more intensive use of modern after-treatment
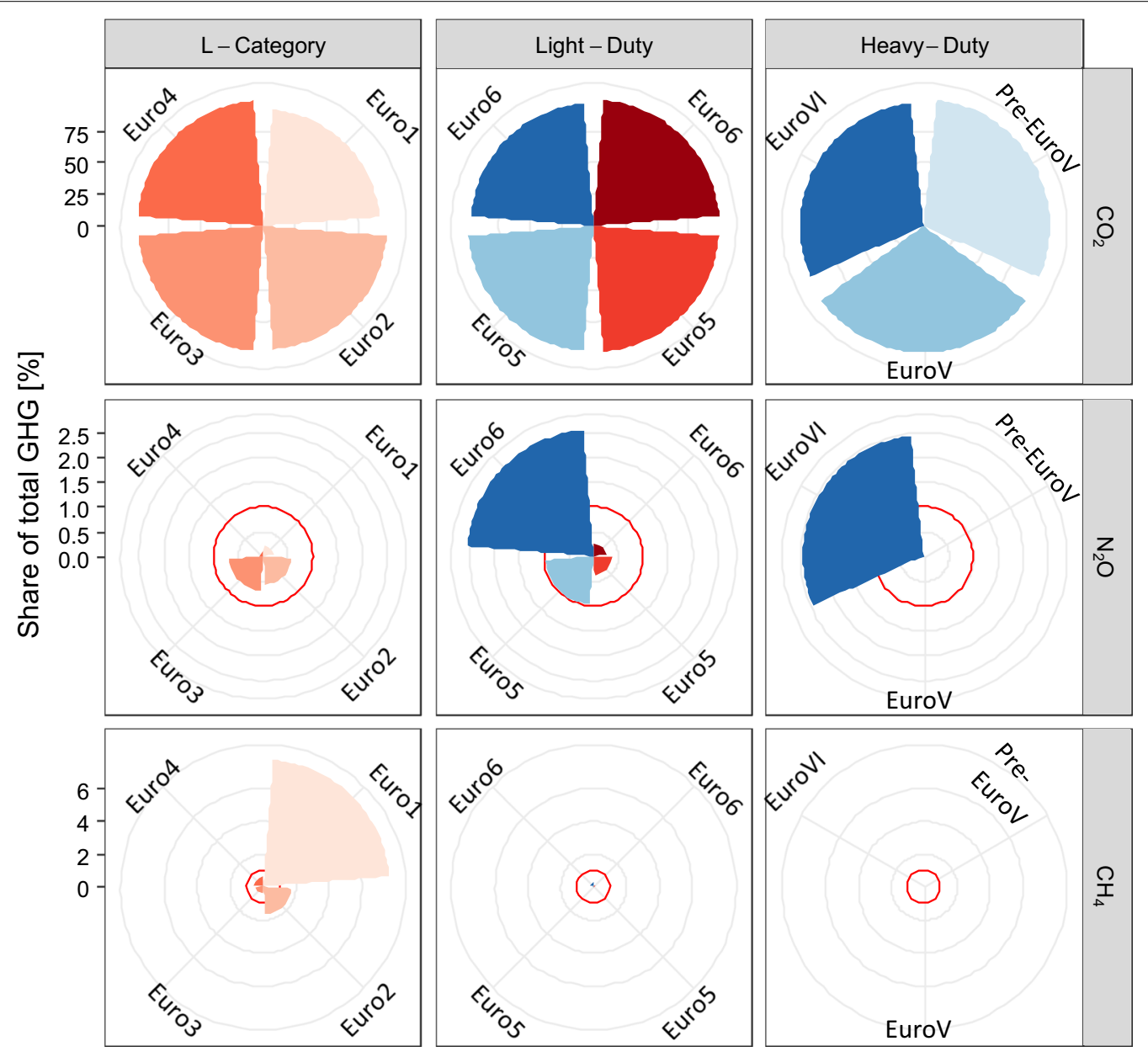

Gasoline

Fig. 8 Share of $\mathrm{CO}_{2}, \mathrm{~N}_{2} \mathrm{O}$ and $\mathrm{CH}_{4}$ emissions, considering the total $\mathrm{GHG}$ emissions from L-category, light-duty and heavy-duty vehicles as a baseline. The facets present the share of each $\mathrm{GHG}\left(\mathrm{CO}_{2}, \mathrm{~N}_{2} \mathrm{O}\right.$ and $\left.\mathrm{CH}_{4}\right)$ in the total $\mathrm{GHG}$ associated to the vehicle category and standard, and the scale is shown on the left. Diesel L-category as well as dual fuel heavy-duty vehicles are excluded. As a help to the eyes, $1 \%$ is represented with a red circle 
system (higher urea injection flow, more frequent LNT/ NSC regeneration) so that diesel light-duty vehicles will be able to comply with the more stringent NOx standards [52, 55, 65]. In such context and without setting a standard on the tailpipe $\mathrm{N}_{2} \mathrm{O}$ emissions from diesel LDV and HDV vehicles, the regulation defined to reduce GHG emissions from on-road transportation will have lower impact on climate change mitigation.

\section{Conclusions}

Greenhouse gas emissions from on-road transport were measured from 128 vehicles from 2009 to 2019. This unique database covered vehicles of different technologies and standards closing the gap in the literature. $\mathrm{CH}_{4}$ average emissions were $39,7.4$ and $19 \mathrm{mg} / \mathrm{km}$ for L-category, light- and heavy-duty vehicles, respectively, with a range between negligible to $320 \mathrm{mg} / \mathrm{km}$. 2-strokers mopeds and a truck dual-fuel CNG appeared to be the largest emitters in their vehicle categories (median emissions of 54 and $221 \mathrm{mg} / \mathrm{km}$, respectively). However, tailpipe emissions of $\mathrm{CH}_{4}$ from two-wheelers are expected to decrease in EU with the introduction of stringent THC limits in the new legislation concerning type approval of mopeds and motorcycles, with the Euro 5 being mandatory by 2020. Light-duty diesel and gasoline vehicles emitted on average $11 \mathrm{mg} / \mathrm{km}$ and $4 \mathrm{mg} / \mathrm{km}$, respectively. Statistical analysis showed that LNT equipped diesel vehicles emitted more than SCR or only DOC equipped vehicles. $\mathrm{N}_{2} \mathrm{O}$ average emissions were 1.4, 6.7 and $19 \mathrm{mg} /$ $\mathrm{km}$ for L-category, light- and heavy-duty vehicles, respectively, with a range between negligible to $118 \mathrm{mg} / \mathrm{km}$. The highest $\mathrm{N}_{2} \mathrm{O}$ emission factors were associated to the modern diesel light (mean $13 \mathrm{mg} / \mathrm{km}$ ) and heavyduty vehicles (mean $19 \mathrm{mg} / \mathrm{km}$ ). This trend was found to increase together with the emissions standards (Euro 5 to Euro 6 and Euro V to Euro VI). The implementation of sophisticated after-treatment system such as LNT/ NSC and SCR is most likely to be the cause of such a shift. The implementation of the Euro 6d-TEMP (mandatory for new type approval since September 2017) for light-duty vehicle includes a new driving cycle (WLTC), and Real Driving Emission tests that may be associated with a more intensive use of after-treatment systems. In this context, $\mathrm{N}_{2} \mathrm{O}$ emissions can be expected to further increase. Consequently, without setting a standard on the tailpipe $\mathrm{N}_{2} \mathrm{O}$ emissions from light- and heavy-duty vehicles, the regulation defined to reduce GHG emissions from on-road transportation might be incomplete.

\section{Supplementary information}

Supplementary information accompanies this paper at https://doi. org/10.1186/s12302-020-00407-5.
Additional file 1. Supplementary Material

\section{Abbreviations}

AMOX: Ammonia oxidation catalyst; ANOVA: Analysis of variance; CNG: Compressed natural gas; CVS: Constant Volume Sampler; DOC: Diesel oxidation catalyst; ECU: Engine Control Unit; ETC: European Transient Cycle; EU: European Union; FTIR: Fourier-transform infrared spectroscopy; GHG: Greenhouse gases; GWP: Global warming potential; HDV: Light commercial and heavy-duty vehicles; JRC: Joint Research Centre; L-cat: L-category vehicles; LCV: Light commercial vehicles; LDV: Light-duty vehicles; LNT: Lean-NOx trap; LPG: Liquefied petroleum gas; NEDC: New European Driving Cycle; NMHC: Nonmethane hydrocarbons; NSC: NOx Storage Catalyst; OEM: Original Equipment Manufacturer; RDE: Real-Driving Emissions; SCR: Selective catalytic reduction; SULEV: Super ultra-low emission vehicle (SULEV); THC: Total hydrocarbons;

VELA: Vehicle Emission Laboratories; WHTC: Worldwide Harmonized Test Cycle; WHVC: Worldwide Harmonized Vehicle Cycle; WLTC: Worldwide harmonized Light vehicles Test Cycle; WLTP: Worldwide harmonized Light vehicles Test Procedure; WMTC: Worldwide harmonized Motorcycle Testing Cycle.

\section{Acknowledgements}

The VELA staff is acknowledged for its skillful technical assistance, in particular, Mauro Cadario, Rinaldo Colombo, Gaston Lanappe, Dominique Lesueur, Mirco Sculati, Christian Bonato, Pierluigi Canevari, Philippe Buchet, Mario Centurelli, Marcos Otura, Giulio Cotogno, Massimo Carriero, Fabrizio Forloni, Fausto Forni, François Montigny, Valter Padovan, Germana Trentadue, Alessandro Zappia,

Frantz Muehlberger and Philippe Le Lijour.

\section{Disclaimer}

The opinions expressed in this study are those of the authors and should in not be considered to represent an official opinion of the European Commission.

\section{Authors' contributions}

The study was designed by MC, BC and CA. MC followed the testing, processed the data and conducted the statistical analysis. AZ, RS, JP and WV helped in post-processing FTIR data. MC drafted the original manuscript. BG, $A Z, R S$, JP and VW, reviewed original manuscript and contributed on specific aspects. All authors read and approved the final manuscript.

Funding

This research received no external funding.

Availability of data and materials

All essential data are part of the article, including Additional file.

Ethics approval and consent to participate

Not applicable.

Consent for publication

Not applicable.

Competing interests

The authors declare that they have no competing interests.

Received: 8 June 2020 Accepted: 18 September 2020

Published online: 01 October 2020

References

1. ACEM, 2017. PRESS RELEASE. European registrations of motorcycles and mopeds continued increasing in 2016: $+9.1 \%$ on a year-on-year basis

2. Adam TW, Chirico R, Clairotte M, Elsasser M, Manfredi U, Martini G, Sklorz M, Streibel T, Heringa MF, DeCarlo PF, Baltensperger U, De Santi G, Krasenbrink A, Zimmermann R, Prevot ASH, Astorga C (2011) Application of modern online instrumentation for chemical analysis of gas and particulate phases of exhaust at the European Commission Heavy-Duty Vehicle Emission Laboratory. Anal Chem 83:67-76. https://doi.org/10.1021/ac101 $859 u$ 
3. Ball D, Moser D, Yang Y, Lewis D (2013) $\mathrm{N}_{2} \mathrm{O}$ emissions of low emission vehicles. SAE Int J Fuels Lubr. 6:450-456. https://doi. org/10.4271/2013-01-1300

4. Behrentz E, Ling R, Rieger P, Winer AM (2004) Measurements of nitrous oxide emissions from light-duty motor vehicles: a pilot study. Atmos Environ 38:4291-4303. https://doi.org/10.1016/j.atmosenv.2004.04.027

5. Blasing TJ (2016) Recent Greenhouse Gas Concentrations. https://doi. org/10.3334/cdiac/atg.032

6. Borillo GC, Tadano YS, Godoi AFL, Santana SSM, Weronka FM, Penteado Neto RA, Rempel D, Yamamoto Cl, Potgieter-Vermaak S, Potgieter JH, Godoi RHM (2015) Effectiveness of selective catalytic reduction systems on reducing gaseous emissions from an engine using diesel and biodiesel blends. Environ Sci Technol 49:3246-3251. https://doi.org/10.1021/ es505701r

7. Bousquet P, Ciais P, Miller JB, Dlugokencky EJ, Hauglustaine DA, Prigent C, Van der Werf GR, Peylin P, Brunke E-G, Carouge C, Langenfelds RL, Lathière J, Papa F, Ramonet M, Schmidt M, Steele LP, Tyler SC, White J (2006) Contribution of anthropogenic and natural sources to atmospheric methane variability. Nature 443:439-443. https://doi.org/10.1038/nature05132

8. Clairotte M, Adam TW, Chirico R, Giechaskiel B, Manfredi U, Elsasser M, Sklorz M, DeCarlo PF, Heringa MF, Zimmermann R, Martini G, Krasenbrink A, Vicet A, Tournié E, Prévôt ASH, Astorga C (2012) Online characterization of regulated and unregulated gaseous and particulate exhaust emissions from two-stroke mopeds: a chemometric approach. Anal Chim Acta 717:28-38. https://doi.org/10.1016/j.aca.2011.12.029

9. Clairotte M, Adam TW, Zardini AA, Manfredi U, Martini G, Krasenbrink A, Vicet A, Tournié E, Astorga C (2013) Effects of low temperature on the cold start gaseous emissions from light duty vehicles fuelled by ethanolblended gasoline. Appl Energy 102:44-54. https://doi.org/10.1016/j. apenergy.2012.08.010

10. Clairotte M, Valverde V, Bonnel P, Giechaskiel B, Carriero M, Otura M, Fontaras G, Pavlovic J, Martini G, Krasenbrink A, Suarez-Bertoa R (2018) Joint Research Centre 2017 light-duty vehicles emissions testing. EUR, Luxembourg, pp 1-90. https://doi.org/10.2760/5844

11. Clairotte, M., Zardini, A.A., Martini, G., 2016. Phase 1 of the Environmental Effect Study on the Euro 5 step of L-category vehicles - Stocktaking and data mining EUR 27994EN, 1-52. https://doi.org/10.2790/428149

12. Dalianis G, Nanaki E, Xydis G, Zervas E (2016) New Aspects to Greenhouse Gas Mitigation Policies for Low Carbon Cities. Energies 9:128. https://doi. org/10.3390/en9030128

13. Davidson EA, Kanter D (2014) Inventories and scenarios of nitrous oxide emissions. Environ Res Lett 9:105012. https://doi.org/10.1088/17489326/9/10/105012

14. EC (2019) Regulation (EU) 2019/631 of the European Parliament and of the Council of 17 April 2019 setting CO2 emission performance standards for new passenger cars and for new light commercial vehicles, and repealing Regulations (EC) No 443/2009 and (EU) No 510/2011 (Text with EEA relevance.). Off J Eur Union OJ L 111:13-53

15. EC (2019) Regulation (EU) 2019/1242 of the European Parliament and of the Council of 20 June 2019 setting CO2 emission performance standards for new heavy-duty vehicles and amending Regulations (EC) No 595/2009 and (EU) 2018/956 of the European Parliament and of the Council and Council Directive 96/53/EC. Off J Eur Union OJ L 198:202-240

16. EC (2017) Communication From The Commission To The European Parliament, The Council, The European Economic And Social Committee And The Committee Of The Regions Delivering On Low-Emission Mobility. COM 2017(675):1-13

17. EC (2017) Regulation (EU) No 2017/1151 of 1 June 2017 supplementing Regulation (EC) No 715/2007 of the European Parliament and of the Council on type-approval of motor vehicles with respect to emissions from light passenger and commercial vehicles (Euro 5 and Euro 6) and on access to vehicle repair and maintenance information, amending Directive 2007/46/EC of the European Parliament and of the Council, Commission Regulation (EC) No 692/2008 and Commission Regulation (EU) No 1230/2012 and repealing Commission Regulation (EC) No 692/2008. Off 」 Eur Union OJ L 175:1-643

18. EC (2014) Commission Delegated Regulation (EU) No 134/2014 of 16 December 2013 supplementing Regulation (EU) 168/2013 of the European Parliament and of the Council with regard to environmental and propulsion unit performance requirements and amending Annex $\mathrm{V}$ thereof. Off J Eur Union OJ L 53:1-327

19. EC (2013) Regulation (EU) No 168/2013 of the European Parliament and of the Council of 15 January 2013 on the approval and market surveillance of two- or three-wheel vehicles and quadricycles. Off J Eur Union OJ L 60:52-128

20. EC (2011) Commission Implementing Regulation (EU) No 725/2011 of 25 July 2011 establishing a procedure for the approval and certification of innovative technologies for reducing $\mathrm{CO} 2$ emissions from passenger cars pursuant to Regulation (EC) No 443/2009 of the European Parliament and of the Council Text with EEA relevance. Off J Eur Union OJ L 194:19-24

21. EC (2011) Commission Regulation (EU) No 582/2011 of 25 May 2011 implementing and amending Regulation (EC) No 595/2009 of the European Parliament and of the Council with respect to emissions from heavy duty vehicles (Euro VI) and amending Annexes I and III to Directive 2007/46/EC of the European Parliament and of the Council. Off J Eur Union OJ L 167:1-168

22. EC (2009) Regulation (EC) No 595/2009 of the European Parliament and of the Council of 18 June 2009 (Euro VI) and on access to vehicle repair and maintenance information and amending Regulation (EC) No 715/2007 and Directive 2007/46/EC and repealing Directives 80/1269/ EEC, 2005/55/EC and 2005/78/EC. Off J Eur Union OJ L 188:1-13

23. EC (2009) Directive 2009/33/EC of the European Parliament and of the Council of 23 April 2009 on the promotion of clean and energy-efficient road transport vehicles. Off J Eur Union OJ L 120:5-12

24. EC (2007) Regulation (EC) No 715/2007 of the European Parliament and of the Council of 20 June 2007 on type approval of motor vehicles with respect to emissions from light passenger and commercial vehicles (Euro 5 and Euro 6) and on access to vehicle repair and maintenance information. Off J Eur Union OJ L 171:1-16

25. EC (2002) Directive 2002/51/EC of the European Parliament and of the Council of 19 July 2002 on the reduction of the level of pollutant emissions from two- and three-wheel motor vehicles and amending Directive 97/24/EC. Off J Eur Union OJ L 252:20-30

26. EC (2000) Directive 1999/96/EC of the European Parliament and the Council of 13 December 1999 on the approximation of the laws of the Member States relating to measures to be taken against the emission of gaseous and particulate pollutants from compression ignition engines for use in vehicles, and the emission of gaseous pollutants from positive ignition engines fuelled with natural gas or liquefied petroleum gas for use in vehicles and amending Council Directive 88/77/EEC. Off J Eur Union OJ L 44:1-155

27. EEA (2017) National emissions reported to the UNFCCC and to the EU Greenhouse Gas Monitoring Mechanism

28. EEA (2016) Annual European Union greenhouse gas inventory 19902014 and inventory report 2016 - Submission to the UNFCCC Secretariat (EEA Report No. 15/2016). Denmark

29. Environmental Protection Agency (2013) 40 CFR Parts 85, 86, 1036, 1037, $1039,1042,1048,1054,1065,1066,1068$ DEPARTMENT OF TRANSPORTATION National Highway Traffic Safety Administration 49 CFR Parts 523 and 535 - Heavy-Duty Engine and Vehicle, and Nonroad Technical Amendments EPA-HQ-OAR-2012-0102, 1-111

30. Giechaskiel B, Clairotte M, Valverde-Morales V, Bonnel P, Kregar Z, Franco V, Dilara P (2018) Framework for the assessment of PEMS (Portable Emissions Measurement Systems) uncertainty. Environ Res 166:251-260. https ://doi.org/10.1016/j.envres.2018.06.012

31. Giechaskiel B, Gioria R, Carriero M, Lähde T, Forloni F, Perujo A, Martini G, Bissi LM, Terenghi R (2019) Emission factors of a Euro VI heavy-duty diesel refuse collection vehicle. Sustainability 11:1067. https://doi.org/10.3390/ su11041067

32. Giechaskiel B, Suarez-Bertoa R, Lahde T, Clairotte M, Carriero M, Bonnel P, Maggiore M (2019) Emissions of a Euro 6b diesel passenger car retrofitted with a solid ammonia reduction system. Atmosphere 10:180. https://doi. org/10.3390/atmos10040180

33. Giechaskiel B, Suarez-Bertoa R, Lähde T, Clairotte M, Carriero M, Bonnel P, Maggiore M (2018) Evaluation of NOx emissions of a retrofitted Euro 5 passenger car for the Horizon prize "Engine retrofit". Environ Res 166:298-309. https://doi.org/10.1016/j.envres.2018.06.006

34. Graham LA, Belisle SL, Rieger P (2009) Nitrous oxide emissions from light duty vehicles. Atmos Environ 43:2031-2044. https://doi.org/10.1016/j. atmosenv.2009.01.002 
35. Graham LA, Rideout G, Rosenblatt D, Hendren J (2008) Greenhouse gas emissions from heavy-duty vehicles. Atmos Environ 42:4665-4681. https ://doi.org/10.1016/j.atmosenv.2008.01.049

36. Grigoratos T, Fontaras G, Martini G, Peletto C (2016) A study of regulated and green house gas emissions from a prototype heavy-duty compressed natural gas engine under transient and real life conditions. Energy 103:340-355. https://doi.org/10.1016/j.energy.2016.02.157

37. Guan B, Zhan R, Lin H, Huang Z (2014) Review of state of the art technologies of selective catalytic reduction of $\mathrm{NOx}$ from diesel engine exhaust. Appl Therm Eng 66:395-414. https://doi.org/10.1016/j.applt hermaleng.2014.02.021

38. Hayhurst AN, Lawrence AD (1992) Emissions of nitrous oxide from combustion sources. Prog Energy Combust Sci 18:529-552. https://doi. org/10.1016/0360-1285(92)90038-3

39. Heeb NV, Forss A-M, Saxer CJ, Wilhelm P (2003) Methane, benzene and alkyl benzene cold start emission data of gasoline-driven passenger cars representing the vehicle technology of the last two decades. Atmos Environ 37:5185-5195. https://doi.org/10.1016/j.atmosenv.2003.04.001

40. Huai T, Durbin TD, Wayne Miller J, Norbeck JM (2004) Estimates of the emission rates of nitrous oxide from light-duty vehicles using different chassis dynamometer test cycles. Atmos Environ 38:6621-6629. https:// doi.org/10.1016/j.atmosenv.2004.07.007

41. IPCC, 2014. Climate Change 2014: Synthesis Report. Contribution of Working Groups I, II and III to the Fifth Assessment Report of the Intergovernmental Panel on Climate Change [Core Writing Team, R.K. Pachauri and L.A. Meyer (eds.)]. Geneva, Switzerland

42. Karlsson HL (2004) Ammonia, nitrous oxide and hydrogen cyanide emissions from five passenger vehicles. Sci Total Environ 334-335:125-132. https://doi.org/10.1016/j.scitotenv.2004.04.061

43. Kelly KJ, Bailey BK, Coburn T, Clark W, Lissiuk P (1996) Federal test procedure emissions test results from ethanol variable-fuel vehicle Chevrolet Luminas. SAE Trans. https://doi.org/10.4271/961092

44. Lang J, Cheng S, Zhou Y, Zhang Y, Wang G (2014) Air pollutant emissions from on-road vehicles in China, 1999-2011. Sci Total Environ 496:1-10. https://doi.org/10.1016/j.scitotenv.2014.07.021

45. Lipman TE, Delucchi MA (2002) Emissions of Nitrous Oxide and Methane from Conventional and Alternative Fuel Motor Vehicles. Clim Change 53:477-516. https://doi.org/10.1023/A:1015235211266

46. Mendoza-Villafuerte P, Suarez-Bertoa R, Giechaskiel B, Riccobono F, Bulgheroni C, Astorga C, Perujo A (2017) NOx, NH3, N2O and PN real driving emissions from a Euro VI heavy-duty vehicle. Impact of regulatory onroad test conditions on emissions. Sci Total Environ 609:546-555. https:// doi.org/10.1016/j.scitotenv.2017.07.168

47. Nam EK, Jensen TE, Wallington TJ (2004) Methane emissions from vehicles. Environ Sci Technol 38:2005-2010. https://doi.org/10.1021/es034 $837 \mathrm{~g}$

48. Nilrit $\mathrm{S}$ (2013) Emission factors of $\mathrm{CH}_{4}$ and $\mathrm{CO}_{2}$ emitted from vehicles. Am J Environ Sci 9:38-44. https://doi.org/10.3844/ajessp.2013.38.44

49. Nisbet EG, Manning MR, Dlugokencky EJ, Fisher RE, Lowry D, Michel SE, Myhre CL, Platt SM, Allen G, Bousquet P, Brownlow R, Cain M, France JL, Hermansen $\mathrm{O}$, Hossaini R, Jones AE, Levin I, Manning AC, Myhre G, Pyle JA, Vaughn BH, Warwick NJ, White JWC (2019) Very strong atmospheric methane growth in the 4 years 2014-2017: implications for the Paris Agreement. Glob Biogeochem Cycles 33:318-342. https://doi. org/10.1029/2018GB006009

50. Saunois M, Bousquet P, Poulter B, Peregon A, Ciais P, Canadell JG, Dlugokencky EJ, Etiope G, Bastviken D, Houweling S, Janssens-Maenhout G, Tubiello FN, Castaldi S, Jackson RB, Alexe M, Arora VK, Beerling DJ, Bergamaschi P, Blake DR, Brailsford G, Brovkin V, Bruhwiler L, Crevoisier C, Crill P, Covey K, Curry C, Frankenberg C, Gedney N, Höglund-Isaksson L, Ishizawa M, Ito A, Joos F, Kim H-S, Kleinen T, Krummel P, Lamarque J-F, Langenfelds R, Locatelli R, Machida T, Maksyutov S, McDonald KC, Marshall J, Melton JR, Morino I, Naik V, Doherty S, Parmentier F-JW, Patra PK, Peng C, Peng S, Peters GP, Pison I, Prigent C, Prinn R, Ramonet M, Riley WJ, Saito M, Santini M, Schroeder R, Simpson IJ, Spahni R, Steele P, Takizawa A, Thornton BF, Tian H, Tohjima Y, Viovy N, Voulgarakis A, van Weele $M$, van der Werf GR, Weiss R, Wiedinmyer C, Wilton DJ, Wiltshire A, Worthy D, Wunch D, Xu X, Yoshida Y, Zhang B, Zhang Z, Zhu Q (2016) The global methane budget 2000-2012. Earth Syst Sci Data 8:697-751. https://doi.org/10.5194/ essd-8-697-2016
51. Suarez-Bertoa R, Astorga C (2018) Impact of cold temperature on Euro 6 passenger car emissions. Environ Pollut 234:318-329. https://doi. org/10.1016/j.envpol.2017.10.096

52. Suarez-Bertoa R, Mendoza-Villafuerte P, Bonnel P, Lilova V, Hill L, Perujo A, Astorga C (2016) On-road measurement of NH3 and N2O emissions from a Euro $V$ heavy-duty vehicle. Atmos Environ 139:167-175. https://doi. org/10.1016/j.atmosenv.2016.04.035

53. Suarez-Bertoa R, Pavlovic J, Trentadue G, Otura-Garcia M, Tansini A, Ciuffo B, Astorga C (2019) Effect of low ambient temperature on emissions and electric range of plug-in hybrid electric cehicles. ACS Omega 4:31593168. https://doi.org/10.1021/acsomega.8b02459

54. Suarez-Bertoa R, Pechout M, Vojtíšek M, Astorga C (2020) Regulated and non-regulated emissions from Euro 6 diesel, gasoline and CNG vehicles under real-world driving conditions. Atmosphere 11:204. https://doi. org/10.3390/atmos11020204

55. Suarez-Bertoa R, Valverde V, Clairotte M, Pavlovic J, Giechaskiel B, Franco V, Kregar Z, Astorga C (2019) On-road emissions of passenger cars beyond the boundary conditions of the real-driving emissions test. Environ Res 176:108572. https://doi.org/10.1016/j.envres.2019.108572

56. Suarez-Bertoa R, Zardini AA, Keuken H, Astorga C (2015) Impact of ethanol containing gasoline blends on emissions from a flex-fuel vehicle tested over the Worldwide Harmonized Light duty Test Cycle (WLTC). Fuel 143:173-182. https://doi.org/10.1016/j.fuel.2014.10.076

57. Suarez-Bertoa R, Zardini AA, Lilova V, Meyer D, Nakatani S, Hibel F, Ewers J, Clairotte M, Hill L, Astorga C (2015) Intercomparison of real-time tailpipe ammonia measurements from vehicles tested over the new worldharmonized light-duty vehicle test cycle (WLTC). Environ Sci Pollut Res 22:7450-7460. https://doi.org/10.1007/s11356-015-4267-3

58. Suarez-Bertoa R, Zardini AA, Platt SM, Hellebust S, Pieber SM, El Haddad I, Temime-Roussel B, Baltensperger U, Marchand N, Prévôt ASH, Astorga C (2015) Primary emissions and secondary organic aerosol formation from the exhaust of a flex-fuel (ethanol) vehicle. Atmos Environ 117:200-211. https://doi.org/10.1016/j.atmosenv.2015.07.006

59. Tadano YS, Borillo GC, Godoi AFL, Cichon A, Silva TOB, Valebona FB, Errera MR, Penteado Neto RA, Rempel D, Martin L, Yamamoto Cl, Godoi RHM (2014) Gaseous emissions from a heavy-duty engine equipped with SCR aftertreatment system and fuelled with diesel and biodiesel: assessment of pollutant dispersion and health risk. Sci Total Environ 500-501:64-71. https://doi.org/10.1016/j.scitotenv.2014.08.100

60. Thiruvengadam A, Besch M, Carder D, Oshinuga A, Pasek R, Hogo H Gautam M (2016) Unregulated greenhouse gas and ammonia emissions from current technology heavy-duty vehicles. J Air Waste Manag Assoc 66:1045-1060. https://doi.org/10.1080/10962247.2016.1158751

61. Tsiakmakis S, Fontaras G, Ciuffo B, Samaras Z (2017) A simulationbased methodology for quantifying European passenger car fleet $\mathrm{CO} 2$ emissions. Appl Energy 199:447-465. https://doi.org/10.1016/j.apene rgy.2017.04.045

62. UNECE, 2011. E/ECE/324/Rev.1/Add.82/Rev.4 or E/ECE/TRANS/505/Rev.1/ Add.82/Rev.4 (26 April 2011) Addendum 82: Regulation No. 83 - Uniform provisions concerning the approval of vehicles with regard to the emission of pollutants according to engine fuel requirements. Off J Eur Union $1-253$

63. UNEP (2013) Drawing down N2O to protect climate and the ozone layer: a UNEP synthesis report. United Nations Environment Programme, Nairobi, Kenya

64. Valverde V, Clairotte M, Bonnel P, Giechaskiel B, Carrier M, Otura M, Gruening C, Fontaras G, Pavlovic J, Martini G, Suarez-Bertoa R, Krasenbrink A (2019a) Joint Research Centre 2018 light-duty vehicles emissions testing EUR 29897EN, 1-118. https://doi.org/10.2760/289100

65. Valverde Mora, Clairotte Pavlovic, Suarez-Bertoa Giechaskiel, Astorga-LLorens Fontaras (2019) Emission factors derived from 13 Euro 6b Light-duty vehicles based on laboratory and on-road measurements. Atmosphere 10:243. https://doi.org/10.3390/atmos10050243

66. Vojtíšek-Lom M, Beránek V, Godoi AFL, Klír V, Jindra P, Pechou M, VoříšekT (2017) On-road and laboratory emissions of $\mathrm{NO}, \mathrm{NO}_{2}, \mathrm{NH}_{3}, \mathrm{~N}_{2} \mathrm{O}$ and $\mathrm{CH}_{4}$ from late-model EU light utility vehicles: Comparison of diesel and CNG. Total Environ, Sci. https://doi.org/10.1016/j.scitotenv.2017.10.248

67. Wallington TJ, Wiesen P (2014) N2O emissions from global transportation. Atmos Environ 94:258-263. https://doi.org/10.1016/j.atmos env.2014.05.018 
68. Zardini AA, Clairotte M, Lanappe G, Giechaskiel B, Martini G (2016a). Preparatory work for the Environmental Effect Study on the Euro 5 step of L-category vehicles EUR 27788EN, 1-140. https://doi.org/10.2790/76508

69. Zardini AA, Platt SM, Clairotte M, El Haddad I, Temime-Roussel B, Marchand N, Ježek I, Drinovec L, Močnik G, Slowik JG, Manfredi U, Prévôt ASH, Baltensperger U, Astorga C (2014) Effects of alkylate fuel on exhaust emissions and secondary aerosol formation of a 2-stroke and a 4-stroke scooter. Atmos Environ 94:307-315. https://doi.org/10.1016/j.atmos env.2014.03.024
70. Zardini AA, Suarez-Bertoa R, Dardiotis C, Astorga C (2016) Unregulated pollutants from tampered two-wheelers. Transp Res Procedia 14:3109_ 3118. https://doi.org/10.1016/j.trpro.2016.05.251

\section{Publisher's Note}

Springer Nature remains neutral with regard to jurisdictional claims in published maps and institutional affiliations.

\section{Submit your manuscript to a SpringerOpen ${ }^{\circ}$ journal and benefit from:}

- Convenient online submission

- Rigorous peer review

- Open access: articles freely available online

- High visibility within the field

- Retaining the copyright to your article

Submit your next manuscript at $\boldsymbol{\nabla}$ springeropen.com 